\title{
A critical review of the impact of South Africa's mine closure policy and the winding-up process of mining companies
}

\begin{tabular}{|c|c|}
\hline $\begin{array}{l}\text { Authors: } \\
\text { Mbalenhle M } \\
\text { Elhadi Adam² } \\
\text { Raeesa Mooll }\end{array}$ & (1) \\
\hline $\begin{array}{l}\text { Affiliations: } \\
{ }^{1} \text { Department } \\
\text { Engineering a } \\
\text { Surveying, Fa } \\
\text { Engineering a } \\
\text { Environment, } \\
\text { Johannesburg } \\
\text { South Africa }\end{array}$ & $\begin{array}{l}\text { f Mining } \\
\text { hd Mine } \\
\text { ulty of } \\
\text { hd the Built } \\
\text { University of } \\
\text { Johannesburg, }\end{array}$ \\
\hline $\begin{array}{l}{ }^{2} \text { School of Gee } \\
\text { Archaeology a } \\
\text { Environmenta } \\
\text { Faculty of Scie } \\
\text { of the Witwat } \\
\text { Johannesburg }\end{array}$ & $\begin{array}{l}\text { graphy, } \\
\text { nd } \\
\text { I Studies, } \\
\text { nce, University } \\
\text { ersrand, } \\
\text { South Africa }\end{array}$ \\
\hline $\begin{array}{l}\text { Correspondin } \\
\text { Mbalenhle M } \\
\text { mmpanza@uj }\end{array}$ & $\begin{array}{l}\text { g author: } \\
\text { panza, } \\
\text { ac.za }\end{array}$ \\
\hline $\begin{array}{l}\text { Dates: } \\
\text { Received: } 20 \\
\text { Accepted: } 15 \\
\text { Published: } 23\end{array}$ & $\begin{array}{l}\text { Jov. } 2020 \\
\text { lune } 2021 \\
\text { Nov. } 2021\end{array}$ \\
\hline $\begin{array}{l}\text { How to cite th } \\
\text { Mpanza M, Ac } \\
\text { R. A critical re } \\
\text { impact of Sou } \\
\text { closure policy } \\
\text { winding-up pr } \\
\text { companies. J } \\
\text { S Afr. 2021;17 } \\
\text { https://doi.or } \\
\text { td.v17i1.985 }\end{array}$ & $\begin{array}{l}\text { is article: } \\
\text { lam E, Moolla } \\
\text { view of the } \\
\text { th Africa's mine } \\
\text { and the } \\
\text { ocess of mining } \\
\text { ransdiscipl res } \\
\text { (1), a985. } \\
\text { g/10.4102/ }\end{array}$ \\
\hline $\begin{array}{l}\text { Copyright: } \\
\text { ๔ 2021. The A } \\
\text { Licensee: AOS } \\
\text { is licensed unc } \\
\text { Creative Comr } \\
\text { Attribution Lic }\end{array}$ & $\begin{array}{l}\text { Iuthors. } \\
\text { IS. This work } \\
\text { der the } \\
\text { nons } \\
\text { ense. }\end{array}$ \\
\hline Read online: & \\
\hline 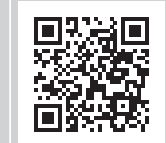 & $\begin{array}{l}\text { Scan this QR } \\
\text { code with your } \\
\text { smart phone or } \\
\text { mobile device } \\
\text { to read online. }\end{array}$ \\
\hline
\end{tabular}

Background: Most mining operations are viable for a period of 30 years, depending on the mineral extracted and the available reserves. Whilst the expectation is that mines will continue uninterrupted until the planned period is complete, unscheduled closure can occur. Sudden and unplanned mine closure can result in immediate environmental and social impacts. In South Africa, the challenges of mine closure are exacerbated by unexpected sudden closures owing to winding-up and business rescue processes. The literature is inconclusive regarding these issues and there is poor integration of affected communities by mining operations.

Aim: We reviewed South Africa's legal frameworks relating to mine closure, the windingup of gold mining companies and the impact of sudden closure on the environment and communities.

Method: This review built on and extended previous systematic reviews. We focused on the regulation for financial provisioning for prospecting, mining, exploration and rehabilitation. Two examples of gold mining companies that were closed prematurely were examined. We also reviewed the mine closure and environmental policies of other countries, notably Australia and Canada and noticed similarities to South African policies.

Results: Differences are evident in the enforcement of compliance in Australia and Canada, which are more proactive in dealing with the challenges of winding-up and its impacts.

Conclusion: South Africa could adopt these countries' models to enforce compliance and proactivity regarding sudden mine closure. One recommendation is to establish a fund for immediate rehabilitation in such cases as part of the temporary mine closure framework.

Keywords: sudden mine closure; liquidation; South Africa; winding-up; socio-economic; environment; impacts; financial provision.

\section{Introduction}

In South Africa, many unscheduled mine closures have occurred in recent years. This phenomenon has left mining communities distressed through environmental degradation and socio-economic effects. In this article, the terms 'unscheduled', 'sudden' and 'premature' mine closure all refer to the same process of closing a mining operation before the planned date.

The processes of winding-up and business rescue sometimes enable mining companies to evade the normal but costly mine closure obligations. ${ }^{1}$ A winding-up process involves an insolvent company being placed under the custodianship of a liquidator, who manages the fair allocation of the company's assets to its creditors, whilst remaining assets go to partners or shareholders. ${ }^{2}$ The purpose of winding-up a company is to cease its existence by dissolution.

Business rescue, by contrast, entails reorganising a financially distressed company to avoid liquidation and restore its profitability. The Companies Act 2008, Section 128(1)(b), defines business rescue as proceedings to facilitate the rehabilitation of a distressed company by providing temporary supervision of the company and management of its affairs and property. ${ }^{3}$ Business rescue provides some relief to recover from temporary liquidity complications or long-term debt by providing an opportunity to restructure business operations. ${ }^{3}$

The premise underlying business rescue is that the 'going concern' value of a company is generally greater than its liquidation or break-up value. The winding-up procedure, by contrast, 
requires the liquidator to send a certificate to the Companies Commission so that the company is dissolved and deregistered. This step ends the existence of the company as a juristic person and its capacity to bear legal rights and obligations. A serious concern is that government statutes cannot enforce compliance or sanctions on a dissolved company.

The winding-up and business rescue processes have led to sudden and forced mine closure, resulting in poor rehabilitation of tailings storage facilities (TSFs), which affects nearby communities. ${ }^{4}$ Moreno et al. ${ }^{5}$ defined 'tailings' as the crushed, sand-like by-product or refuse material that is generated during the extraction, crushing, grinding and milling procedures of mined ore. Tailings are rock and other waste materials removed as impurities when waste mineral material is separated from the metal in an ore. The tailings from gold mining contain long-living cyanide metal complexes, naturally occurring radioactive materials and technologically enhanced naturally occurring radioactive materials. They also contain a broad spectrum of metals in elevated concentrations, such as aluminium, manganese, arsenic (a metalloid), lead, iron, copper and cobalt. Generally, TSFs are located on privately owned properties. However, the owners have no legal responsibility - or finance - to remine, reuse and rehabilitate the materials. ${ }^{6}$

When a mine is closed, considerable trauma and frustration affect the surrounding mining community. The distress results from job losses; safety threat issues associated with 'Zama Zama' (illegal miners) invading the disused shafts, electricity cuts, poor health and contamination of the soil, water and air. ${ }^{7}$ Abandoned mine shafts are believed to host about 70000 illegal miners. ${ }^{7}$ Adler et al..$^{6}$ called these effects on the community and environment as the 'externalisation of costs' ${ }^{6}$

In South Africa, successful mine closure is difficult to achieve even with community and government agreement on process and objectives. The difficulty is exacerbated when closure is sudden owing to a mining company's liquidation. The complexity arises from the notion that the government is responsible for enforcing compliance and promoting the industry whilst also protecting human rights. The government finds it difficult to strike a balance and appears not to take proper responsibility for closed mines, which means mining companies may opt for liquidation and sudden mine closure. Mine closure has been known to occur when revenue streams dropped below the cost of operating the mine. ${ }^{6}$

In recent years, the labour costs per kilogramme for gold mining have risen, whereas productivity has remained largely unchanged. ${ }^{8}$ This has resulted in some gold mining shafts being abandoned, poorly rehabilitated, informally closed or placed under care and maintenance. This problem occurs because of the legacy of mining companies being obliged to generate maximum profit for their shareholders an approach endorsed by the government.
The World Bank predicts that in the next 25 years, several mines will close in developing countries. ${ }^{9}$ The trend is already evident in South Africa and Zimbabwe, with mines either being closed, placed under care and maintenance or abandoned. ${ }^{9}$ Given the environmental problems with abandoned mines, policy implementation needs to be reviewed and strengthened.

This article reviews mine closure policy and its interaction with the winding-up procedure in South Africa. The Aurora Empowerment System, the Blyvooruitzicht Gold Mining Company (BGMC) and the Mintails Mining South Africa Pty Ltd. (MMSA) group of companies provide classic examples of sudden mine closure through a winding-up procedure. There is little research on identifying the key drivers of sudden closure. The known drivers include liability shifting amongst companies, unclear regulatory leadership on care and maintenance, challenges in enforcing an integrated closure plan and generic company regulation, poor mine planning, business rescue and the winding-up procedures.

This article focuses on the winding-up process as the main driver of unscheduled or poorly executed mine closure in the BGMC and MMSA case studies. Laurence ${ }^{10}$ observed that only a small percentage of mines are closed according to the mine closure plan; most are closed prematurely or suddenly for various reasons. ${ }^{10}$ Milaras and McKay ${ }^{11}$ contended that numerous mines lack contingencies or specific plans for sudden or emergency closure. Marais ${ }^{12}$ and Milaras and McKay ${ }^{11}$ argued that there is a lack of institutional capacity regarding mine closure decisionmaking, compliance monitoring and enforcement. There are also insufficient long-term studies on mine closure impacts and remediation. The lack of rehabilitation by mining companies owing to sudden mine closure is seen by human rights and environmental activists to undermine Section 24 of the South African Constitution. Section 24 states that every person has the right to an environment that is not harmful to their health or well-being. ${ }^{13}$

The objectives of this article are as follows:

- To examine the interaction of mine closure policy and the winding-up process of mining companies in South Africa.

- To review the effect of the interaction between mining and company laws.

- To understand what happens in other countries regarding mine closure and the winding-up process of mining companies and to derive lessons from those experiences.

\section{Methods}

\section{Literature review}

This study used no primary data but reviewed existing literature on policies pertaining to mine closure and the winding-up of mining companies. The review built on and extended previous systematic reviews. The review process involved searching for publicly available literature on mine closure and sudden mine closure. We examined 
international conference articles, peer-reviewed journal articles, theses, books, policy documents, guidelines, government publications, newspapers and company reports and tool-kits. Primary themes and key words were identified from these sources to assist with further literature search.

Several academic databases were used, such as Google Scholar, Scopus, African Mines online, Engineering Village, Chemical Rubber Company (CRC) netBase, Geoscience World and the South African Bureau of Standards. Other internet sites visited include the Department of Mineral Resources and Energy (DMRE), the Department of Environmental Affairs (DEA) (now called Department of Forestry, Fisheries and Environment), the Centre for Environmental Rights and Lawyers for Human Rights (LHR). Library catalogues were consulted to locate available material on library shelves and additional databases were suggested by librarians. Where additional information was needed, the process was repeated.

The keywords used during the search were limited to subjects concerning mine closure and mine liquidation or insolvency. We excluded oil, gas and marine mining. The sources obtained from the search were ordered according to the most cited, to select the most recent, relevant and valuable literature on the subject. Journal articles were located through indexing and abstracting publications.

As mentioned, the two case studies of BGMC and MMSA provided examples of the interaction between mining, environmental and company laws. We paid close attention to the dust impacts from TSFs after the sudden closure of these mining companies because of liquidation.

\section{Content analysis}

The articles, books and policy documents that met the search criteria were assessed according to relevance. A summary of all the literature search categories includes publication details, author details (reference), location of the study or document, the scale or unit of analysis, commodity, year and research subject matter.

Policy documents were reviewed to identify any existing gaps. The main legislative documents referred to were the Companies Act 71 of 2008, the Companies Act 61 of 1973, the Insolvency Act of 1936, the Mineral and Petroleum Resources Development Act 28 of 2002 (MPRDA) and amendments, the National Environmental Management Act 107 of 1998 (NEMA) and the Minerals Act 50 of 1991. The sub-regulations accompanying these Acts were also reviewed, as were any supplementary Acts.

\section{Findings}

Adler et al. ${ }^{6}$ stated that mine regulation in the post-apartheid era has not been successfully implemented, despite mining having occurred for over 130 years. ${ }^{6}$ Poor implementation is mainly the result of lack of specificity or inter- and intra- departmental disagreements about policies. This scenario has resulted in the mismanagement and abandonment of mine tailings or dumps, as evident in the South African landscape. Humby ${ }^{14}$ stated that there is a disjuncture between the regulated mine closure model and the winding-up process as stipulated in the Companies Act 61 of 1973. The disconnect is evident in the winding-up procedure versus the rules of transfer of mining rights, financial provisions and final closure.

This article focuses on the disjuncture between the winding-up procedure and the financial provisions. We noticed that this is a crucial issue in most prematurely closed and liquidated mining companies. ${ }^{14}$ It also appears to have a direct impact on poor rehabilitation of the environment and communities.

\section{Corporate distress in South African mines}

'Corporate distress' is defined in Chapter 6 of the Companies Act 61 of 2008 as a company appearing reasonably unlikely to be able to pay all its debts when they fall due or within the ensuing 6 months. Alternatively, it appears reasonably likely that the company will become insolvent within the ensuing 6 months. ${ }^{3}$ Corporate distress is becoming common amongst gold mining companies in South Africa. Examples are Pamodzi Gold, Aurora Empowerment System, Lily Mine, Shiva Uranium Mine and the BGMC and MMSA group of companies. These companies either had to be placed under business rescue or were liquidated.

This scenario is not unique to South Africa. In Australia, United Kingdom, Poland and Spain (amongst others), corporate distress has been prevalent since 2013. ${ }^{15}$ The main challenge faced by mining companies is cash flow limitation. This problem is exacerbated by the time lag between the initial outlay for labour and services versus the recouping of costs from commodity sales. Limited global economic growth is another factor. The downward pressure on commodity prices and rising costs such as wage pressure may also impact in the medium term. In numerous cases, the corporate distress of mining companies can lead to sudden mine closure. The World Bank Group ${ }^{16}$ stated that mining projects may be curtailed unexpectedly because of falling metal prices, technical difficulties or financial problems of the company.

Corporate distress in South African mining results in premature mine closure, which exacerbates the complexity of the regulated mine closure process. Humby ${ }^{14}$ stated that struggling mines are placed under care and maintenance or business rescue and liquidation to avoid the liabilities associated with closure.

This article discusses two procedures - business rescue and winding-up - through which a mining company expresses corporate distress. We focus mainly on winding-up because our case studies underwent this process, leading to liquidation. Furthermore, winding-up generally results in sudden closure of mine operation. 
'Business rescue' is defined in the Companies Act 61 of 2008, as mentioned in the introduction of this article. The rationale of this procedure is twofold: firstly, to serve the public interest through a remedy directed at avoiding the deleterious consequences of liquidations where there is a reasonable prospect of salvaging the business of a distressed company. Secondly, to secure a better return for creditors that could be achieved through immediate liquidation.

'Winding-up' is defined in Chapter 14 of the Companies Act 61 of 1973 and Winding-up Regulations (Winding-up Regulations GN2490, 1973). The term refers to a process whereby insolvent companies are placed under the custodianship of a liquidator, who then manages the fair and equitable allocation of the company's property amongst its creditors. ${ }^{2}$

A company's major and minor shareholders or the company creditors can voluntarily initiate either process without informing government statutory bodies. However, doing so contradicts the provisions set out in the MPRDA 28 of 2002. These provisions stipulate that once a company initiates mine closure processes, a closure certificate needs to be issued, which requires the involvement of the Department of Forestry Fisheries and the Environment (DFFE), the Department of Water and Sanitation (DWS) and the DMRE. ${ }^{17}$ A closure certificate is issued only after the Chief Inspector of Mines and DWS confirms in writing that the company has complied with provisions regarding health and safety and the management of potential water pollution. When the process of winding-up is initiated first that requirement is evaded because a company can be dissolved and suddenly close without a closure certificate.

\section{Mine liquidation in South Africa}

Winding-up is regulated under several Acts in South Africa. However, for insolvent companies, liquidation is regulated by the Companies Act 61 of 1973 and the Winding Up Regulations. $^{2}$ The purpose of liquidation is to dissolve the company in an orderly manner and not to rescue it. The company's existence ceases through the formal process of dissolution.

Winding-up may also be conducted before creating a new company. The Companies Act 61 of 1973 distinguishes between winding-up by a court (compulsory winding-up) and voluntary winding-up. The latter can be initiated either by a creditor or by members. According to the rules for these processes, the main distinction is between members' voluntary winding-up and creditors' winding-up versus compulsory winding-up by a court. The common feature in compulsory winding-up and voluntary creditors' windingup is that the company is insolvent and is thus unable to pay its debts.

This is a specific ground upon which a company may be wound-up by the court under Section 344 of the Companies Act 61 of 1973 . Section 345 sets out the circumstances in which a company is deemed unable to pay its debts. ${ }^{2}$ Like a members' voluntary winding-up, a creditors' voluntary winding-up is initiated by resolution of the members, with no particular circumstances or reasons being required. In practice, however, the circumstance in which creditors would want to wind-up the company would be its inability to pay its debts.

An early example of a mining company that experienced winding-up was the Aurora Empowerment System. Its takeover of Pamodzi Gold Ltd. was finalised in October 2009. Since 2008, Pamodzi had operated a mine in Orkney, one of the richest gold mining areas in South Africa. ${ }^{18,19}$ Issues that arouse included employees not receiving their salaries in the post-liquidation period.

Sudden mine closure is common in South Africa and has direct repercussions for the environment and surrounding communities. In the BGMC case, a tailings storage facility was left unrehabilitated, and soon after the sudden mine closure, the wind blew the dust towards the nearby communities. The dust became a serious nuisance ${ }^{4}$ and was perceived as a health threat by the community. Blyvooruitzicht Gold Mining Company had no closure certificate and was liquidated in 2013 when a sale between Durban Roodeport Deep (DRD) Gold and Village Main Reef (VMR) fell through. The liquidator and activists failed to gain access to the BGMC financial provision, which was still managed by Durban Roodepoort Deep Gold (DRDGOLD) personnel. ${ }^{14}$ According to Olalde, ${ }^{20}$ the Promotion of Access to Information Act (PAIA) documents showed that the funds were worth about R35 million - which DRDGOLD admitted was inadequate to clean up the mine. However, the financial provisions of BGMC increased to $\mathrm{R} 43 \mathrm{~m}$ because of interest, and the total liabilities were listed as more than R891m. The Trust Fund amount of R43m was transferred to BGMC's new owner, Blyvoor Gold Capital (Pty) Ltd.

Another example of a liquidated mining company is MMSA. It holds three mining rights that cover 1751 ha near Krugersdorp. ${ }^{20}$ Mintails required about R259m to complete the rehabilitation regarding those rights, but this figure was far too low, according to the environmental management programme (EMP) report. ${ }^{8}$ At the time of the liquidation of MMSA and Mintails Gold (Pty) Ltd, the company only legally held one mining right, namely MR 206 (for the reclamation of sand dumps and TSFs). When the Mintails Group of companies acquired MR 132 and MR 133 (open cast and hard rock mining), these rights were not approved by the Minister of Mineral Resources and Energy. ${ }^{21}$ The Mintails Group of companies nonetheless continued to mine the Princess Pits, the Lancaster Pit, the Monarch and Emerald cluster of pits and the Platinum Group of Metals cluster of pits.

The PAIA documents reveal that the company and related entities hold less than R17m in funds for rehabilitation..$^{21}$ It is estimated that 260 permanent employees and 500 contractors lost their jobs through the liquidation of MMSA. Furthermore, the surrounding communities were left with several partially 
rehabilitated TSFs, which generate dust and contribute to acid mine drainage. They are used by children as playgrounds. This poses a health threat to surrounding communities as the gold tailings contain hazardous heavy metals. ${ }^{10}$

\section{Mine closure in South Africa}

Mine closure planning is part of the mine life cycle, which includes exploration, pre-feasibility, development through operations and finally closure and rehabilitation. Closure planning is multidimensional and mutually dependent on the surrounding communities. ${ }^{22}$ In South Africa, mine closure is regulated under the MPDRA and the NEMA 107 of 1998 as amended by the DMRE and DFFE regulatory authorities. In technical terms, the mine closure process commences with the mining right applicant's preparation of an EMP prior to authorisation. This process continues through the operation; it ends when a closure certificate is issued by the Minister of Mineral Resources and Energy.

The best practice in mine closure planning is to consider closure even at the prospecting phase, when the feasibility of the mine and the design and mining permits are established..$^{23}$ International best practice for mine closure involves setting social and environmental objectives, identifying ecological essentials, selecting and implementing appropriate technology and monitoring the ecological surrounds. Mines normally close at the end of the mine's life cycle when the mineral resources and reserves are depleted. However, recently mines have closed prematurely for various reasons, including economics, politics and geological complexities. ${ }^{13}$ Mining operations also close before the environmental and social obligations have been fulfilled.

Fourie and Brent ${ }^{24}$ stated that South Africa has adequate policies and legislature on mine closure, especially regarding social and community development. The promulgation of the MPRDA was aimed at ensuring that mining companies take responsibility regarding community growth and development. The Act sets out objectives that must be achieved during closure. They include the following points: eliminating immediate harm to human health and safety, ensuring that ground and surface water are fit for domestic use, eliminating the risk of harm to non-aquatic organisms and ensuring that soil is fit for current and future land use. ${ }^{23}$

The MPRDA Section 38 (2) contains provisions that hold directors of registered mining companies and members of closed corporations accountable for any degradation, deprivation or contamination. ${ }^{25}$ Section 39 of this Act stipulates that an Environmental Impact Assessment (EIA) and EMP must be undertaken by the applicant. These processes can help to identify, mitigate and manage environmental impacts originating from the mine's closure and aid decommissioning and rehabilitation after the closure. Section 40 makes provisions for consultation with, and involvement by, government departments during closure and decommissioning.
The MPRDA Section 43 (3) states that the holder of a mining right or permit must apply for a closure certificate upon cessation of mining operations or on relinquishing any portion of land to which the right or permit relates. Section 43 also mentions closure planning. ${ }^{24}$ Until mid-2014, mine closure planning was regulated by the MPRDA. Since then, it has been regulated under NEMA as a sustainable development construct. However, some of the elements of mine closure, such as relinquishment, are still regulated by the MPRDA. The National Environmental Management Act imposes the duty of care and remediation of environmental degradation on any person who causes, has caused or may cause degradation. Section 2 of NEMA provides specific guidance on the closure of mining operations. It requires a mining right holder to:

- Rehabilitate the environment as far as reasonably practicable to its natural state or to a land use that conforms to the generally accepted principle of sustainable development.

- Set aside a financial provision, which only the state can access, to ensure such rehabilitation.

- Retain liability for environmental damage even after closure of the operation.

Most attention has focused on the financial provision, the duration of liability and the gaps that allow companies to contract out of their mine closure obligations. ${ }^{26}$ The provision only applies if the new order mining right has been issued for a particular mining company. In the case of BGMC, the new order mining right was not issued prior to liquidation; hence, neither the DMRE nor the liquidator could step in to take care of the community and avoid environmental degradation.

Brent and Fourie ${ }^{24}$ stated that there are two key challenges that arise when mine closure occurs, which include environmental rehabilitation and the dependency of mining communities on operational mine activities. However, mine closure is framed by standards describing the quality of mine rehabilitation. They include five regulatory techniques, namely (1) forward planning for mine closure, (2) financial provision for rehabilitation, (3) flexible monitoring for oversight during the operational phase, (4) state-approved final closure and (5) transfer of environmental risks and liabilities. This article focuses on financial provisioning for rehabilitation regulation because it has direct implications for the liquidation of a mining company. The regulation is discussed in the following sention.

\section{Financial provisions for prospecting, exploration mining and rehabilitation}

'Financial provisions refer to the funds set aside for managing the environmental impact of mine closure as a common regulatory technique. ${ }^{27}$ In South Africa, Section 41 of the MPRDA requires mines to make financial provision for rehabilitation upon closure. These provisions were determined under Regulations 53 and 54 and guidelines published by the Department of Minerals and Energy. ${ }^{28}$ Section 41 (1) of the MPRDA and Section 24P of the NEMA 
require the provision of trust funds for rehabilitation purposes, with a financial guarantee from a South African registered bank and a cash transfer into an account specified by the director general. The financial provision must include a detailed list of all costs required for premature or unscheduled closure, decommissioning and final closure, as well as post-closure management of residual or latent environmental impact (Regulation 54). ${ }^{27}$

Mines must assess their environmental liability annually and increase the financial provision to the satisfaction of the minister (Section 41.3, MPRDA). ${ }^{17}$ If the annual review reveals a shortfall in funds, the rights holder must increase the provisions within 90 days of the date of signature of the auditor's report (Regulation 114a, Financial Provisioning Regulations of 2005).

In 2005, the Department of Minerals and Energy published the Guideline Document for the Evaluation of the Quantum of Closure-Related Financial Provision Provided by a mine. The guidelines provide for quantifying various closure components. The quantum of financial provision must include a detailed itemisation of costs required for unscheduled closure, decommissioning and final closure and the post-closure management of residual and latent environmental impacts.

Humby ${ }^{14}$ observed that there is no official guideline for quantifying social closure costs, although large mining companies - such as Anglo American and De Beers - have done some work in this area. The only instance where social issues regarding mine closure are observed in the MPRDA is through the Social and Labour Plan (SLP). The SLP addresses issues about how the employer should deal with retrenchments and downscaling when mine closure is certain (Regulation 46d). ${ }^{29}$ The World Bank Group ${ }^{16}$ stated that it is important to consider social costs when predicting possible financial implications and final closure costs.

Humby ${ }^{14}$ added that the provisions in Section 41 of the MPRDA and Section 24P of the NEMA offer little protection in instances of company liquidation, and the Insolvency Act of 1936 does not cover financial provision for rehabilitation. The issue here is that the primary statutory authority regarding the allocation of funds upon a company's demise is not the Insolvency Act but the Companies Act 61 of 1973.

In November 2015, Financial Provisions Regulations were promulgated for implementation by NEMA. Requirements in the NEMA regulation Government Notice Regulation (GNR) 1147 stipulate that the financial provisions must be audited by an auditor registered with the Independent Regulatory Board for Auditors. The audit must be conducted annually with comprehensive reconciliation. National Environmental Management Act's GNR 1147 supersedes Section 41 and regulations 53 and 54 of the MPRDA.

National Environmental Management Act requires that the rights holder must assess environmental liability in a prescribed manner and increase the financial provision to the satisfaction of the minister responsible for mineral resources (Financial Provision Regulation, GNR 1147). ${ }^{27}$ The GNR 1147 regulation requires the consideration of, and provision for, possible latent or residual environmental impacts. This includes remediation of environmental impacts such as the pumping and treatment of polluted or extraneous water. When a closure certificate is issued, the financial provision of latent and residual impacts may be ceded to the DMRE. The financial provision regulation considers only social risk, contingency statements and cash risk in the audited financial statements. The social and long-term economic consequences do not appear to be a priority, yet there is much emphasis on the availability of funds to address the long-term environmental consequences of mining. ${ }^{12}$

In January 2016, the mining industry raised concerns and requested clarity from the Deputy Director General of the then DEA about the 2015 Financial Provisioning Regulations. The concerns included limitation on trust funds, inclusion of funds for annual rehabilitation, care and maintenance funds and requests for extensions on the implementation of the Financial Provisioning Regulations. In November 2017, revised regulations were gazetted for public comment (Government Gazette 41236 under Government Notice (GN) R1128, Draft Regulations). In 2018, the focus was on consultations between stakeholders, professionals and Parliament and holding interdepartmental meetings. In May 2019, a proposed revision of the Financial Provisioning Regulation was published for comment. ${ }^{30}$

The revised regulation in Chapter 3 of the Financial Provisioning Regulation includes cancellation, withdrawal and claiming against a financial guarantee; claiming against a trust fund, closure rehabilitation company or cash deposit and withdrawal against a financial provision to facilitate decommissioning and final closure. ${ }^{30}$ These provisions had not been included in the original Financial Provisioning Regulations. It is anticipated that the new provisions will deal with the challenges of mine liquidation and business rescue. For example, Regulation 9 deals with the fact that the Minister of Mineral Resources and Energy can initiate a claim against the financial guarantee to effect remediation and rehabilitation. ${ }^{30}$ Subregulation 9 (4) (a) states that the minister must provide the holder, liquidator or business rescue administrator and the financial institution with written notice of the intention to initiate a claim, including the reasons for such claim. This provision did not exist in the 2015 Financial Provisioning Regulations and is yet to be exercised by the minister.

Regulation 10 deals with claiming against the trustees or directors of a fund or closure rehabilitation company or from the financial provision deposited into the account administered by the minister for that holder. Subregulation 10 (1) states if the holder, liquidator or business rescue administrator fails to initiate actions to rehabilitate within 30 days after being ordered to do so, the minister may 
order the trustees or directors of the trust fund or closure rehabilitation company to deposit an identified amount into the account administered by the minister. This amount will enable the minister to undertake the rehabilitation on behalf of the holder.

The aforementioned provisions seem reactive instead of preventative. They both discuss only what actions the minister can take should the rights holder, liquidator or business rescue administrator fail to initiate rehabilitation and closure. It appears that the 2019 Financial Provisioning Regulations will still emphasise environmental rehabilitation over the socio-economic impacts. The regulations do not contain provisions that would enable interested and affected parties to make representations if the financial provisions for a specific prospecting, mining, exploration or production operation are inadequate. Such provisions would be congruent with the national environmental management principle in Section 2 of NEMA. This section states that the participation of all interested and affected parties in environmental governance must be promoted and in line with the requirements of the Promotion of Administrative Justice Act 3 of 2000 (PAJA). ${ }^{31}$

As mentioned in Sections Corporate distress in South African mines and Mine liquidation in South Africa of this article, winding-up through liquidation is becoming a working strategy for some mining companies that wish to evade the costly closure obligations. The mine closure framework itself provides little detail regarding sudden closure. This fact causes confusion amongst stakeholders regarding what should happen in the case of sudden, unscheduled or premature closure. Milaras ${ }^{32}$ argued that unless authorities and responsibilities are clearly indicated and monitored, mine closure cannot be successfully performed in South Africa.

Olalde,$^{20}$ an investigative journalist, studied the financial provisions for mine closures and rehabilitation. Olalde ${ }^{20}$ compiled, curated and analysed data in a series of investigations on mine closure trust funds, financial provisions for rehabilitation and closure certificates. 'Mine Closures: What's happening in your backyard?' was a multimedia production - for which Olalde sourced information from MMSA to complement his desk research with field research and interviews. He obtained information through the PAIA 3 of 2000 (PAIA, 2000) provided by the Federation for a Sustainable Environment (FSE). His work showed that between July 2012 and July 2015, no closure certificate was granted for mining rights held in the Gauteng province. Hence, none of the closed mines had been officially closed or followed the formal regulated mine closure framework.

Olalde's second investigation showed that coal mines leave a legacy of ruin. Since 2011, no large coal mines in South Africa had been granted closure certificates. Hence, some mines that were supposedly closed had not been rehabilitated but were

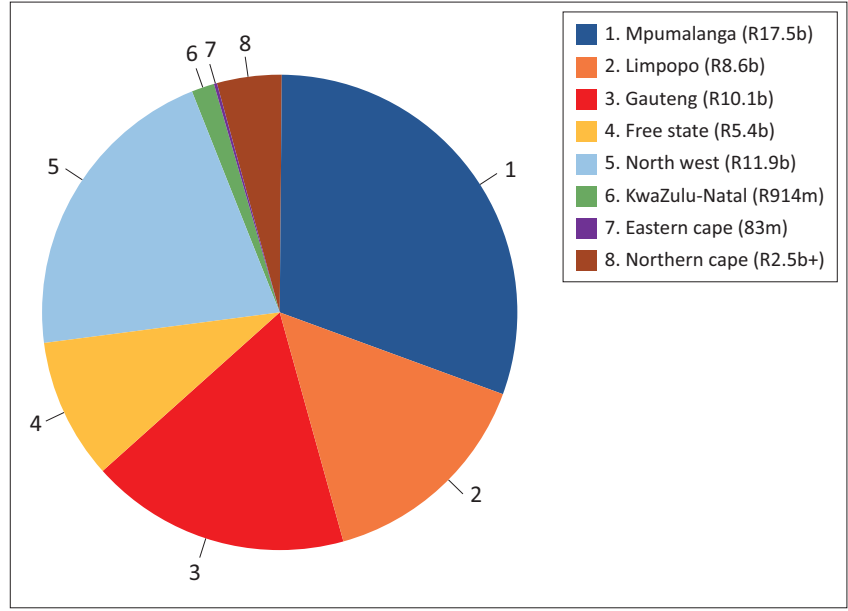

Source: Olalde M. SA's failed system of mine closure [homepage on the Internet]. 2017 [cited 2018 Feb 5]. Available from: https://www.iol.co.za/news/opinion/sas-failed-system-of-mineclosure-7117963

$\mathrm{m}$, million; $\mathrm{b}$, billion.

FIGURE 1: Financial provisions for rehabilitation in each province. ${ }^{20}$

simply abandoned, leaving local and global pollution. The third and final investigation exposed the R60-billion being held in mine rehabilitation funds across South Africa for mines that might never be closed. This investigation exposed:

$[A]$ failed system of mine closure in which there is little flexible monitoring and oversight [and] large mining houses carry the brunt of responsibility for financial provisions that are never used and mines that are never fully closed. ${ }^{32}$

Figure 1 illustrates the financial provisions that remain available in each province of South Africa.

It is evident that funds are available to clean up after mining pollution. Yet, it is unclear where these funds are currently held and what rehabilitation has been done to date. Since 2012, the Council for Geoscience and the DMRE have collaborated to rehabilitate derelict and ownerless mines. Annual updates on the project are provided in the Council for Geoscience annual report. The 2016-2017 annual report states that there were delays in rehabilitation projects in Gauteng ${ }^{33}$; the reasons given were collusion in the issuing of tenders and a challenge with illegal miners. The report stated that these issues were being resolved. However, it was clear that some abandoned mines in Gauteng remain unrehabilitated..$^{33}$

\section{Socio-economic aspects of mine closure}

Studies have documented the multifaceted nature of mine closure..$^{32}$ Various stakeholders have unique needs relating to mine closure. For example, mine owners want minimal liability within a reasonable time frame for closure, whereas the government does not want to incur financial or environmental and social liabilities. ${ }^{20,32,34,35}$ Affected communities want the opportunity to maintain and improve their quality of life post-closure. In most mining areas, the mining activity replaced subsistence farming and communities were rendered dependent on the mine. This dependence creates numerous challenges when a mine closes, including loss of employment and businesses. ${ }^{34}$ 
Van Eeden et al., ${ }^{35}$ Stacey et al. ${ }^{23}$ and Du Plessis ${ }^{36}$ all discussed the socio-economic implications of mine closure for host communities. These range from trauma through unemployment and loss of income or lack of self-employment to safety threats, depression, uncertainty, pollution and ecological degradation. The socio-economic impacts include an undeveloped local economy, poorly developed infrastructure and lack of economic opportunities and activity. ${ }^{37}$ Communities are robbed of potential livelihood opportunities and agricultural activities and jobs are diminished. In the post-mining phase, agricultural activities never fully recover to the pre-mining level. The soil pollution from deposited toxic dust or precipitated contaminated water results in soils unfit for agricultural activities. ${ }^{38}$ These impacts are amplified when a mine closes suddenly through liquidation, owing to additional shock and trauma to the employees and surrounding community and businesses.

The Mining Charter's Broad-Based Black Socio-Economic Empowerment (B-BBEE) is a South African governmental instrument designed to promote sustainable growth and meaningful transformation in the mining industry. The Charter promotes equitable access to the nation's mineral resources for all South Africans and expands opportunities for historically disadvantaged South Africans or persons. Furthermore, it promotes employment and advances the social and economic welfare of mine communities and major labourproviding areas. $^{39}$ The Mining Charter and SLP are two frameworks that address socio-economic issues in the MPRDA.

A draft Mining Charter was released in 2018 and is yet to be finalised. ${ }^{39}$ Section 2.5 of this Charter acknowledges that mining communities are an integral part of mining development, which requires a balance between mining and the community's socio-economic development. It further states that mining companies should contribute meaningfully both in terms of impact and adhering to the principles of the social license to operate. ${ }^{39}$ A social license to operate signifies community buy-in for a project and helps a company to access local knowledge. The social licence for a mining company to operate should deal with a meaningful contribution to community development.

The community participation process establishes the legitimate key players in the community and provides them with a mandate. Good engagement with communities is also necessary to ensure that expectations are managed. This process limits the potential for external exploitation of the community and enhances community participation in identifying post-project options. Ultimately, the community should take ownership of post-closure initiatives. This approach essentially manages sustainability risks and facilitates the avoidance of costly legacies on closure.

The Mining Charter ${ }^{39}$ is solid in its requirements. However, Section 2.1.1.7 states that a company may contribute subject to its solvency and liquidity as defined in the Companies Act of 2008. This provision suggests that a company could be exempt from making contributions detailed in the Charter depending on its liquidity status. Hence, mining companies might be able to avoid fulfilling their SLPs, leaving surrounding mine communities destitute and without benefit from their host mines. The Mining Charter sets no time-line regarding when a company should make contributions to community development and projects. The period for mining companies to fulfil their social obligations is open-ended, which allows for diverse interpretation by individual companies and communities. These points are significant gaps in the Mining Charter and they mean that sudden mine closure can occur before the social obligations are fulfilled. Naidoo ${ }^{40}$ also pointed out that, although policy developments mention socioeconomic impacts, there is no clarity on what these are and how they will be addressed.

Durand $^{41}$ argued that the Mining Charter exacerbates the complexity of mine closure. For example, large mining corporations may sell their marginal operations to junior B-BBEE companies, which often lack the financial capacity to rehabilitate the mine sites. When the junior company cannot further finance its operations, it files for bankruptcy, leading to abandoned mines and premature or sudden closure. The suddenly closed mine leaves behind in many instances poorly rehabilitated TSFs, which become a cost for the surrounding community.

\section{The issue of dust}

The pollution of air, soil and water caused by mining activities and the poor rehabilitation of TSFs has detrimental impacts on the health and well-being of surrounding communities. In 2016, the Human Rights Commission ${ }^{42}$ conducted a study on mining-affected communities in South Africa. They reported that most communities complained about increased levels of dust, deteriorating health, water pollution and food insecurity. Communities have drawn attention to poor environmental remediation and overall management. ${ }^{42}$ According to Anglo Gold Ashanti, ${ }^{43}$ as of 1997, South Africa has produced an estimated 468 million tonnes of mineral waste per annum. Gold mining waste accounts for 221 million tonnes or $47 \%$ of the total making it the largest single source of pollution and waste. ${ }^{38}$ Water pollution, especially in the Witwatersrand Basin is of great concern, as acid water fills up the old mine shafts decanting into the environment. Polluted air from TSFs also contributes to the acid water by depositing high concentrations of metals, sulphides and salts on surrounding water surfaces. Air pollution by windblown dust from TSFs is a significant health issue because when it is inhaled depending on the size fraction can affect lung tissue.

The three key national acts that have consequences for minerelated dust are the National Environmental Management: Air Quality Act 39 of 2004 (NEMAQA), NEMA and MPRDA. National Environmental Management Act acknowledges that the state's environmental obligation is linked to the responsibility to respect, protect and fulfil socio-economic rights. Environmental degradation arising from the failure to 
rehabilitate TSFs infringes on human and socio-economic rights. Environmental rights are associated with rights to food, water, health, land and dignity.

Anglo Gold Ashanti ${ }^{43}$ reported that more than 300 tailings dams exist in the Witwatersrand Basin, which covers $400 \mathrm{~km}^{2}$ of land. By introducing the MPRDA, NEMA and One Environmental System, the state attempted to redress the negative environmental impacts of mining. The One Environmental System (OES) was established in 2014 and allows for the environmental management of mining through a single environmental system. It shifted the statutory authority for environmental management of mining to the environmental legislation and split the implementing authority between the DMRE and the DFFE. ${ }^{1}$

Air pollution in the form of dust from unrehabilitated TSFs can cause respiratory disease amongst surrounding communities. Nkosi, Wichmann and Voyi ${ }^{44}$ found that exposure to mine dumps or residing near a mine dump posed an increased risk of respiratory disease. Illnesses such as asthma, chronic bronchitis, chronic cough, emphysema, pneumonia and wheezing are associated with close proximity to mine dumps (less than $5 \mathrm{~km}$ ). ${ }^{44}$ The respiratory illness is triggered by fine-grained tailings material that are inhaled; the dust also contains toxic heavy metals.

Air quality monitoring and management are regulated under the NEMAQA. In 2013, the then DEA released the National Dust Control Regulations, founded on the need to prevent pollution and ecological degradation and to realise Section 24 of the South African Constitution. Moreover, Section 33 of NEMAQA requires mining companies to notify the Minister in writing if mining operations are likely to cease within a period of 5 years. ${ }^{45}$ Despite all these regulations and standards being in place, non-compliance remains prevalent in the mining industry, especially the gold sector. Companies are suddenly closed because of winding-up, without having informed the minister in writing that the mine is insolvent and expected to close. This point is discussed in the BGMC and MMSA case studies here. Oelofse ${ }^{38}$ observed that cooperative governance remains ineffective to protect the environment against mining waste's negative impacts.
In Soweto, communities residing in close proximity to tailings dumps experience ongoing respiratory illnesses. ${ }^{46}$ International Human Rights Clinic Harvard Law School ${ }^{47}$ (IHRCHLS) mentioned the chemical toxicity of the Witwatersrand tailings dumps, which contain significant levels of arsenic, cadmium, cobalt, uranium, lead and zinc. ${ }^{35,48,49}$ Uranium is of the greatest concern because it is radioactive; when broken down, it releases a toxic gas called radon. When radon is inhaled or ingested, it can cause brain damage and cancer in the long term. ${ }^{35}$

\section{Two South African case studies Blyvooruitzicht}

Blyvooruitzicht is a gold mining town located $6 \mathrm{~km}$ southwest of Carletonville in the Gauteng province, South Africa. Blyvoor gold mine commenced in 1937 and continued until August 2013, when BGMC was placed under provisional liquidation. ${ }^{14}$ The mine was renowned for being the richest gold-bearing mine in the world. ${ }^{50}$ It was liquidated approximately 14 years ahead of schedule owing to a slumping market and labour disputes. The mine generated about $£ 2.5 \mathrm{~m}$ in gold, silver, uranium and other minerals, but it is now a volatile wasteland..$^{51,52}$

Before the sudden closure of the mine, there were 10 tailings dams (slimes) on the mine property, of which only two were active. Slime dam 6 was the disposal area, and slime dam 1 was utilised as a disposal area in emergencies. Figure 2 shows dam 6, located in close proximity $(60 \mathrm{~m})$ to the community of Blyvooruitzicht mine village (also called 'Blyvoor'). During the liquidation period, tailings storage facility 6 was perceived by the community to be a source of dust fallout (Figure 2). ${ }^{4}$

In 2016, when residents of Blyvooruitzicht were interviewed by LHR, they mentioned that the air was not clean. ${ }^{52}$ The district just west of the city had recorded 42.24 metric tonnes of tailing-pile dust blowing into the air daily, contaminating livestock and food crops. Residents in the LHR study said that tailings caused health problems including cancer, asthma, rashes, eye irritation and eczema..$^{52}$ However, the lack of local epidemiological studies means that communities living near
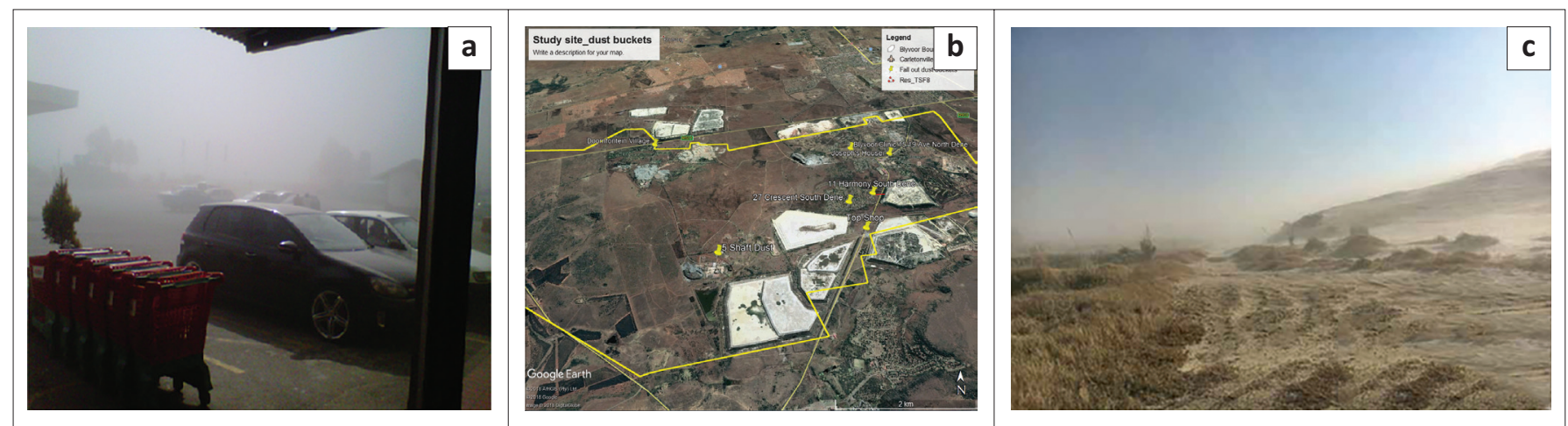

FIGURE 2: (a) Tailings storage facility 6, (b) located close to the community, with (c) dust fallout. 
mine dumps cannot easily pursue litigation against mining companies. Residents also mentioned that there had been several deaths in the area because of illnesses such as tuberculosis, which they believed were caused by the dust. ${ }^{4,52}$

Blyvooruitzicht Gold Mining Company is one of the oldest gold mines in Carletonville, South Africa. In 1997, DRD Gold Limited acquired majority shareholding in BGMC and took over the gold mine operations. After the takeover, DRD Gold updated the EMP to comply with the MPRDA. The new EMP included a conceptual closure plan and a life of mine plan, which indicated that mining would cease in 2027..$^{51}$ The EMP also detailed the short- and long-term rehabilitation and closure activities regarding decommissioning and final closure of the mine. However, this EMP was never approved by the Department of Mineral Resources.

In June 2011, BGMC voluntarily placed itself under supervision and business rescue in terms of the Companies Act of 2008. ${ }^{53}$ Later that year, VMR concluded an agreement with DRD Gold for a $74 \%$ acquisition of BGMC, which then nullified the business rescue process. The acquisition was conditional on (1) the DMRE converting the BGMC old order mining right to a new order mining right and (2) approval by the Minister of Mineral Resources and Energy to conduct a Section 11 of the MPRDA, which is the transfer of mining rights. ${ }^{54}$

In July 2013, VMR issued a stock exchange notice that its board of directors had resolved to pull out of the BGMC agreement because of continuing losses. In August 2013, DRD Gold announced that it would not fund BGMC operations. Gold prices around this time plummeted to an all-time low, creating challenges in sustaining the mine or even proceeding with the process of closure. ${ }^{54}$ After all these announcements, the BGMC directors resolved to place the company under compulsory winding-up by court order in terms of the Companies Act 61 of 1973.

In the trust fund, the category of fixed assets shows that only $\mathrm{R} 35 \mathrm{~m}$ is available for financial provision for rehabilitation. However, approximately R108m would be required for environmental rehabilitation. ${ }^{54,55}$ Furthermore, these figures contradict the amount reported in the updated EMP, namely R75m. The FSE, a non-profit company of environmental activists, has attempted to obtain accountability from the company through litigation, with no success.

Humby ${ }^{14}$ argued that although the regulated closure model in the MPRDA appears to be in order, the right to transfer mining rights as per Section 11 of the Act is ambiguous in terms of ownership and liability. Humby ${ }^{14}$ further stated that the winding-up process governed by the Companies Act 61 of 1973 and the Insolvency Act of 1936 poorly articulates the mine closure model. This scenario results in inadequate protection of the financial provision for environmental rehabilitation. The rehabilitation of the environment and the social issues arising from either sudden or scheduled mine closure appear to be overlooked in the regulated model. Humby ${ }^{14}$ further described the challenges associated with sudden mine closure through winding-up in South Africa.

The gold mining operation of Blyvoor is now under a new owner, known as Blyvoor Gold Capital. This company purchased some of the assets previously owned by BGMC with the hope of starting production and providing jobs for the BGMC employees and the wider community.

\section{Mintails South Africa (Pty.) Ltd.}

Our second case study on mine liquidation is MMSA, also known as the Mintails Group. It operated in the Krugersdorp area, west of Johannesburg and focused on mining and processing gold. ${ }^{21}$ The company had 260 permanent employees and 500 contractors. The company was wound-up in August 2018. Informal settlements still surround the mine, and the residents report negative health impacts caused by radioactive dust. ${ }^{21}$

Environmentalists, regulators and activists have been reporting the non-compliance of the Mintails Group since 2015. Hence, state officials were aware of the transgressions long before the final liquidation in 2018 - yet no legislation was enforced. An estimated R330m would be required for environmental clean-up, but only R20m is available for such rehabilitation. ${ }^{21}$ According to the CEO of the FSE, the Mintails Group exploited mineral resources by mining only the profitable parts and failed to top up the financial provisions annually.

Mintails denies some of its environmental liability, claiming that the issues predated their involvement. However, the law states that the rights holder acquires the liabilities with the new order rights. ${ }^{17}$ Figure 3 shows the environmental impact from unrehabilitated TSFs of MMSA. Lucien Limacher, an attorney at the Legal Resources Centre, stated that it has become a trend for mines to opt for business rescue or liquidation after failing to set aside annual funds for rehabilitation. ${ }^{21}$ Mintails has an estimated total liability of R485 967 811, which includes R258 749771 for rehabilitation. Furthermore, it has also been reported that MMSA has not complied with their SLP commitments. ${ }^{55,56}$ This situation

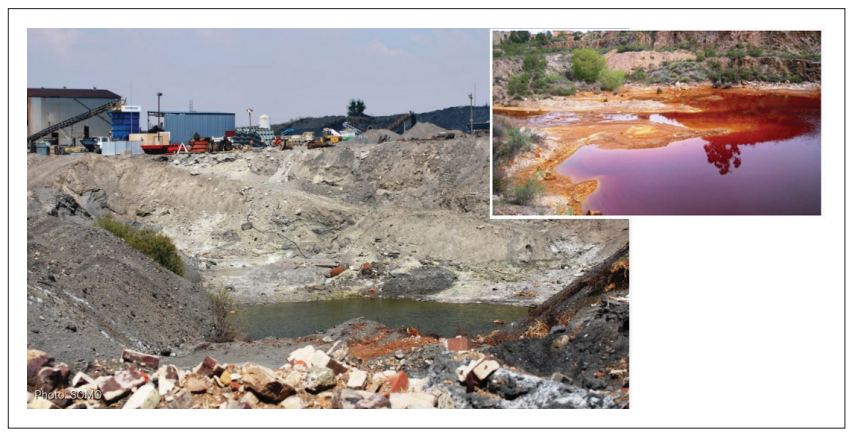

Source: Photos courtesy of Mbalenhle Mpanza and Mariette Liefferink FIGURE 3: Mintails South Africa: Tailings storage facilities site. 
meant that some Mintails Group mining rights were granted but were never issued.

The most widely discussed and visible types of mine closure are abandonment and terminal closure. The latter occurs when an ore body is mined out and the company - after reclamation and rehabilitation - permanently ceases its operations. The given case studies have revealed that in reality, mines are 'temporarily' closed for political, economic, market, technical, environmental or social reasons; there may be an expressed intention to reopen, but this rarely happens. The case studies have also shown that there was a lack of mine closure planning by both companies. There was no evidence of contingency planning, forward planning for mine closure or adequate estimated closure costs in the EMPs. Inadequate funds had been set aside for rehabilitation by the time the mines were liquidated, which indicates a lack of monitoring and annual review of financial provisions. The lack of adequate mine closures that have already taken place and issues regarding the transparency and accessibility of closure documents makes it very difficult to verify the adequacy of a mine's financial provision.

The financial provision for closure was set aside as trust funds for the two companies, indicating that some companies fail to manage their own funds.

Furthermore, the case studies highlight the lack of enforcement by the DMRE through allowing mining companies to operate without an issued mining right, as was the case with MMSA. Only when sudden mine closure occurs is everything revealed, namely that DMRE was not enforcing compliance with the mine closure plan. Mining companies use either business rescue or the winding-up processes to opt out of their obligations as set out in the mining and environmental regulations.

\section{The international sphere}

According to Andrews et al., ${ }^{57}$ historically, many countries viewed mine closure as the mere stoppage of production and mine decommissioning. Mining companies thus disregarded the fact that mine closure is multifactorial. It has social, environmental and financial effects. ${ }^{58}$ Closed mines need rehabilitation and monitoring and the safe removal of equipment, plant and dangerous materials. The pits and TSFs must be safeguarded whilst the land is restored.

In the 1960s, limited funding was set aside for mine closure costs and the policies addressing the issue were inadequate. ${ }^{57}$ Countries such as Australia, Chile and Saudi Arabia had mines that required forced or premature closure. In these cases, policies had to be established to prioritise mine closure amongst stakeholders - which included governments, communities and mining companies.

Most countries have mine closure requirements within their mining laws or the associated implementing rules and regulations for mining laws or within specific environmental legislation that is applicable to the mining sector. ${ }^{59}$ The International Organisation for Standardisation in 2017 admitted that there is no global standard on mine closure and reclamation management. However, countries such as Australia and Canada partially provide best-practice examples for the world.

Internationally, the minerals and metals sector has been under increasing pressure not only to improve social and environmental performance but also to demonstrate that it is making real contributions to sustainable development. The very concept of sustainable development originates from public awareness of the pollution of natural sites through industrial activities. The International Council on Mining and Metals (ICMM) insists that planning for closure should be a core business practice of mining companies. ${ }^{60}$ The ICMM issued an integrated approach to closure, which considers environmental and social matters to realise sustainable development. ${ }^{61}$ In 2019, the ICMM produced guidelines for good practice in mine closure. These guidelines promote integrated mine closure planning, which means that closure should be integrated into the systems and decisions behind a mine's operations. Hence, mine closure planning should not be treated as a separate process tagged onto a project close to the end of a mine's life.

Figure 4 illustrates the ICMM ${ }^{22}$ mine closure framework. Mine closure is considered early in a mining project and extends throughout the mine's cycle, in line with Canada's National Orphaned and Abandoned Mines Initiative policy. ${ }^{22}$ The next sections of this article focus on international regulations and requirements for mine closure and compare the South African situation with that of other countries.

\section{Australia}

The final decision to close a mine occurs when there is no viable financial return from the mining operations. However, the Minerals Council of Australia accurately defines closure as a process, which begins during the pre-feasibility phase of a mining project and continues through operations until lease relinquishment. The mine closure policy sets clear objectives and guidelines, makes financial provision and establishes effective stakeholder engagement, leading to successful relinquishment of the lease.$^{62}$ Hence, in Australia, closure is no longer thought of as an end-of-line procedure but rather as a planning process aimed at reducing long-term environmental impacts even before they become a problem. It is also aimed at reducing the financial burden of final closure and rehabilitation. ${ }^{62}$

Mining in Western Australia (WA) has occurred for more than 150 years and many mines have been abandoned after initial exploration or mining. Approximately $70 \%$ of Australian mines have been closed in the past 25 years, mostly as unexpected or unscheduled closures. ${ }^{13}$ The abandoned mines caused health, safety and environmental risks. The potential cultural, social, environmental, 


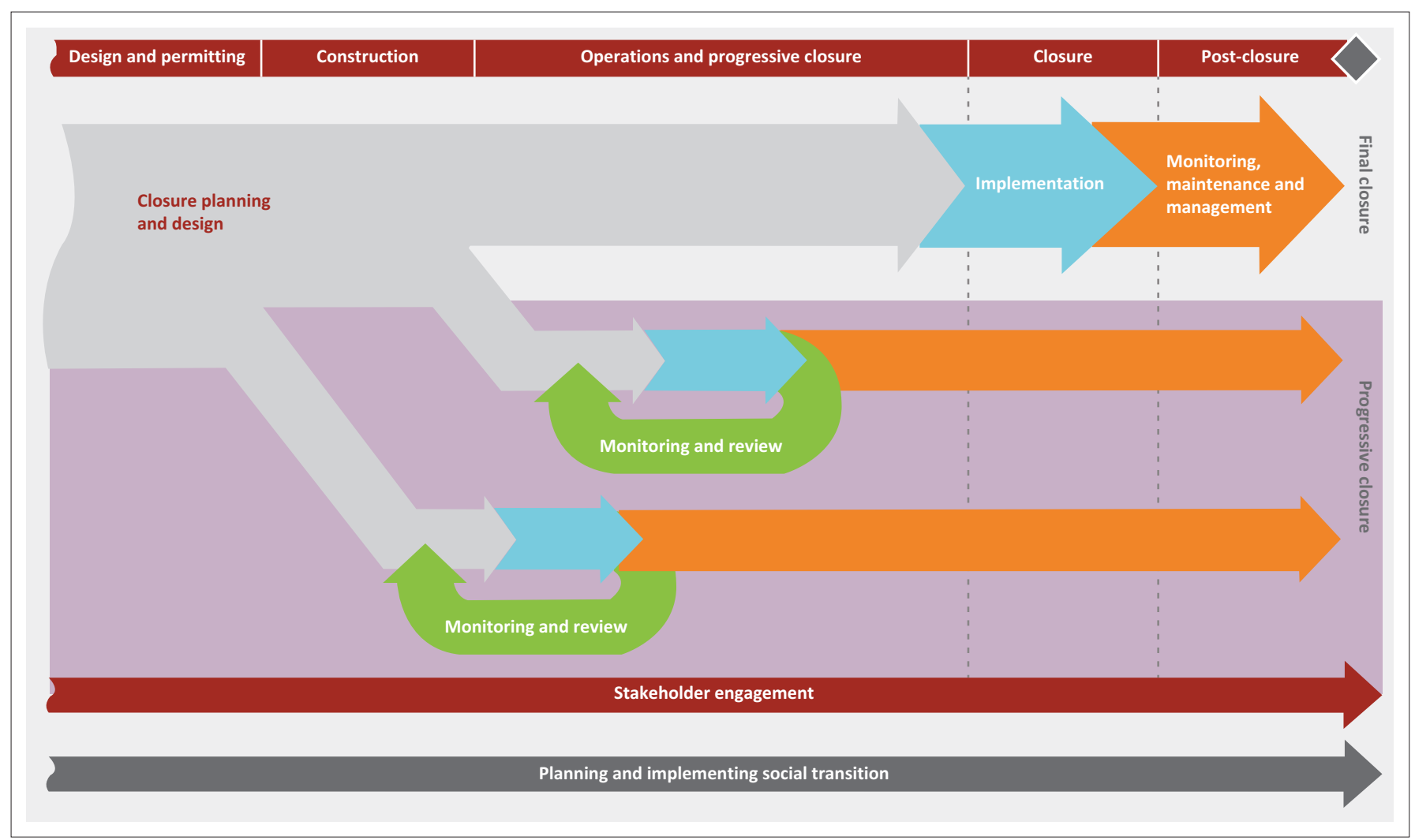

Source: ICMM. Planning for integrated mine closure: Toolkit. London: International Council on Mining and Metals; 2019.

FIGURE 4: Integrated mine closure good practice. ${ }^{22}$

educational or economic value of these sites remains unknown. In the 1980s, environmental impact became a key consideration for the approval of mineral exploration and mining. Guidelines for mining were established by the state Department of Minerals and Energy and contain technical details of rehabilitation applicable to tailings facilities. ${ }^{63}$ The department required that decommissioned TSFs must be safe, stable and aesthetically acceptable. ${ }^{61}$

More recently, in 2010, the Western Australian Department of Mines and Petroleum (DMP) became responsible for the sustainable and responsible management of the resources sector in WA. The Environmental Protection Authority is responsible for assessing mine closure under Part IV of the Environmental Protection Act of 2015. In 2011, the DMP and Environmental Protection Authority collaborated and released the Guidelines for Preparing Mine Closure Plans, which were updated in 2015. To apply for a prospecting right or permit (mining proposal in Australia), a mine closure plan must first be submitted in accordance with the guidelines. ${ }^{64,65}$ The guidelines specify that rehabilitated mines must be safe for humans and animals, stable, non-polluting and capable of sustaining an agreed post-mining land use. ${ }^{64}$

The objective of the Environmental Protection Act of 2015 is to ensure that mine premises are rehabilitated in an ecologically sustainable manner. In the Northern Territory of Australia, the broad objective for mine closure is that sites must be rehabilitated to a standard that minimises or negates restrictions on subsequent land use - both at the site and surrounding it. ${ }^{63}$ Reclamation plans form part of the mine closure plan and must be submitted to the competent agency for approval together with an environmental management plan. After adequate rehabilitation, the mining property is returned to the owner or the state. The minister of mines, land and environment then signs off the project and a relinquishment certificate is issued.

The mine closure plan guidelines require the identification of completion criteria to demonstrate that closure objectives are detailed in the plans. The completion criteria must include performance indicators, trends and projections to predict any long-term impact. The closure guidelines also cover financial provisions for closure; this requirement entails sufficient funds for closure being held and for the affected community not to be left destitute. ${ }^{66}$ Financial provisions should be held in corporate accounts specifically for mine closure costs.

Australia has a Mining Rehabilitation Fund that is regulated by the Mining Rehabilitation Fund Act of 2012. The purpose of the fund is to secure long-term funding for the state to rehabilitate abandoned mines and other land affected by mining. ${ }^{67}$ This is a 'superfund', which contributes in addition to the financial provisions; it cannot be used to offset the financial provisions..$^{63}$ Moreover, in 2016, Australia released an abandoned mine policy. It comprises a risk assessment strategy of how abandoned mines should be prioritised and rehabilitated. Community engagements and input are needed at each stage of development of a closure plan. Upon 
submission, relevant agencies review the plan and approvals are announced within 30 days of submission. ${ }^{68}$

Regarding the winding-up of a mine, our document review identified a case in Queensland that was handled by Colin Biggers and Paisley Lawyers. A coal gasification mining company called Linc Energy Limited was liquidated in 2016. Two laws were applied during the liquidation period, namely the Corporations Act of 2001 and the Environmental Protection Act of $1994 .{ }^{68}$ In April 2016, Linc Energy appointed liquidators as administrators of the company. In May 2016, the Department of Environment and Heritage Protection issued an environmental protection order (EPO) to the liquidators. In June 2016, the liquidators issued a notice disclaiming the land, site infrastructure and the environmental assessments (EAs) under section 568(1) of the Corporations Act of 2001. The department took possession of the land and facilities. The matter was referred to the High Court, which did not accept the liquidator's submissions. The judge ruled that liquidators are executive officers under the Environmental Protection Act; hence, if they fail to comply with this law, they commit an offence. ${ }^{69}$

It thus appears that Queensland deals accordingly with the winding-up of a mining company through the Environmental Protection Act. Where an EPO is issued to a company to secure compliance with the general environmental duty under Section 319 of the Environmental Protection Act, liquidators cannot evade the company's obligation to comply with the EPO by disclaiming the land or infrastructure. In the given case, the EPO was issued prior to the disclaimer, but the judge's reasoning implies that the timing of the disclaimer and the issuance of the EPO were irrelevant. The liquidators were still required to fulfil environmental compliance.

\section{Canada}

In Canada, the federal government and 13 provinces govern environmental and mining regulations. The federal law is, however, considered superior to the environmental statutes in case of conflict. ${ }^{65}$ Municipalities and communities also play a significant role in mining and environmental regulation. The federal Supreme Court ruled that communities that used the land before it was mined have the right to be meaningfully consulted regarding the development and closure of mines.

Provincial governments are responsible, on behalf of society, for enforcing efficient and effective legislation regarding the development of mineral resources and the management of waste sites. ${ }^{70}$ Mining companies are required to submit their mine closure plans before they are granted approval to initiate mining. In Canada, mine closure can take between 2 and 10 years to complete; however, in cases where long-term monitoring of environmental and other impacts is indicated, decades can elapse before the closure is concluded..$^{71}$

British Columbia pioneered legislation on reclamation, which aims to ensure that once operations cease, the mine- site land is restored to a useful, productive standard. ${ }^{72}$ Environmental assessments are required by the EA Act of 1995 before mining projects are approved in British Columbia. The EA process includes a conceptual-level decommissioning and reclamation plan. The plan involves long-term objectives for future use of the land after decommissioning. Assurance regarding reclamation and closure activities is required in the EA plan.

British Columbia's Mines Act of 1989 and the Health, Safety and Reclamation Code make provisions for minimising the health, safety and environmental risks linked to mining. A mine must apply for a permit from the Chief Inspector of Mines under the Mines Act before ground disturbance can take place. The permit protects the land and water and requires a reclamation programme and permit holders must estimate the total costs for their reclamation obligations over the planned life of the mine. The Mineral Resources Division in the Ministry of Energy and Mines provides assurance that the province will not contribute to reclamation costs if a mining company defaults on its reclamation obligations. ${ }^{72}$

The Mines Act also requires permit holders to post-financial security in funds, in a form accepted by the Chief Inspector of Mines. This security is accepted in several forms, such as cash certified cheques, bank drafts, term deposits, government bonds and irrevocable standby letters of credit. ${ }^{65}$

Each province in Canada has mine closure guidelines, namely British Columbia, Ontario, Quebec, Saskatchewan, Northwest Territories and Manitoba. ${ }^{68} \mathrm{~A}$ common requirement amongst them is a conceptual closure plan to be submitted as part of the application for mining development. Closure plans are supposed to be reviewed every 3-5 years. The plans are submitted together with the impact management plans, which cover land reclamation, revegetation and the remediation of environmental and socio-economic impacts of affected mining communities and employees. Environmental protection agencies oversee and monitor the progress of closure plans.

In June 2016, 10\% of mining companies were delisted from the Toronto Stock Exchange in Canada because of formal insolvency proceedings. These proceedings had doubled between 2014 and 2015. However, the delisted 10\% represented only 16 companies, probably because the capital structure of junior mining companies tended to be financed with equity (as explained here). Furthermore, there were difficulties in accounting for fixed assets in various jurisdictions and remote locations.

Canadian law provides ways for insolvent companies to prolong the process until they can either devise a restructuring plan or find a buyer. Canada's main corporate restructuring law is the Companies' Creditors Arrangement Act of 1935 (CCAA). This Act allows a court to impose a freeze to prevent creditors from suing an insolvent company that owes more than $\$ 5 \mathrm{~m}$. The freeze enables the company to continue operations whilst it negotiates a deal with creditors. However, 
exploration and development juniors generally fund their operations through equity. Hence, they do not necessarily have enough debt to seek reorganisations under the CCAA. They can instead seek relief under the Bankruptcy and Insolvency Act of 1985. This Act allows companies with debts of over $\$ 1000$ to present creditors with reorganisation proposals or to wind up their operations with liquidation. It is common for junior mining companies to have no operating revenue; as a result, they may be able to place their properties under care and maintenance.

\section{Summary}

Regardless of the approach or the requirements, the plans for rehabilitation, reclamation and mine closure vary in detail amongst and within individual countries. So do the requirements for financial provision and other surety instruments to ensure that the plans are carried out.

Several similarities and differences are observed in the regulations of South Africa and those of other countries. For example, Australia requires the approval of mine closure plans and surety regarding financial provisions for mine closure even before a mining project is approved and the same is required in South Africa. However, the Australian government provides a Mine Rehabilitation Fund to aid with rehabilitation on closure; such a fund does not exist in South Africa.

In Australia, the enforcement of environmental laws is the responsibility of environmental protection agencies, whereas in South Africa, is it the Mineral Resources and Energy Department. ${ }^{73}$ In both countries, the Minister of Mines, the Minister of Land and the Minister of the Environment must all sign off on closure and issue a certificate of abdication.

Canada requires an impact management plan and a mine closure plan, which must be approved by provincial regulators. Furthermore, community participation during the planning and implementation of mine closure is regarded as a crucial contribution if the closure is to be successful. ${ }^{74}$ Canada also requires the company to set funds aside for closure, reclamation and rehabilitation, ${ }^{75}$ and South Africa and Australia have the same requirement.

\section{Discussion}

\section{Disjuncture in policy}

From a compliance perspective, sudden mine closure through liquidation of a mining company presents challenges. When a mining company applies for a provisional liquidation, there is no provision in the Companies Act 61 of 1973 to ensure that the company has been issued with a closure certificate. Furthermore, there is no mention in the Companies Act 61 of 1973 that there must be adequate financial provision before the court will grant provisional or final liquidation. It is not even clear whether, in terms of government statutes, government is included as a creditor in the financial provisions. It is not clear whether the liquidator is responsible for environmental rehabilitation, or whether they must apply for a closure certificate during the provisional liquidation period.

The Companies Act 61 of 1973 predated any comprehensive attempt to regulate mine closure by statute. Hence, one would not expect to find explicit references and points of articulation with this process. Nevertheless, the provisions of this Act could be relevant to the extent that they:

- Determine the ambit of 'property', 'assets' and 'liabilities' for purposes of winding-up proceedings.

- Articulate notice requirements and access to information.

- Set out the role and responsibilities of directors, the liquidator, and the master during the winding-up process.

Figure 5 presents the evolution of laws pertaining to mining and the environment, compared with company laws. The reasons for disjuncture between the laws are summarised in the figure. Notably, the Companies Act 61 of 1973 predated any attempts to regulate mine closure. Only in 1991 did the mining regulation introduce the concept of mine closure plans through the Minerals Act 50 of 1991. This statutory measure came into effect when most mines were already operational. ${ }^{25,27}$ Hence, mines did not have to consider proactive contingency planning ahead of possible closure.

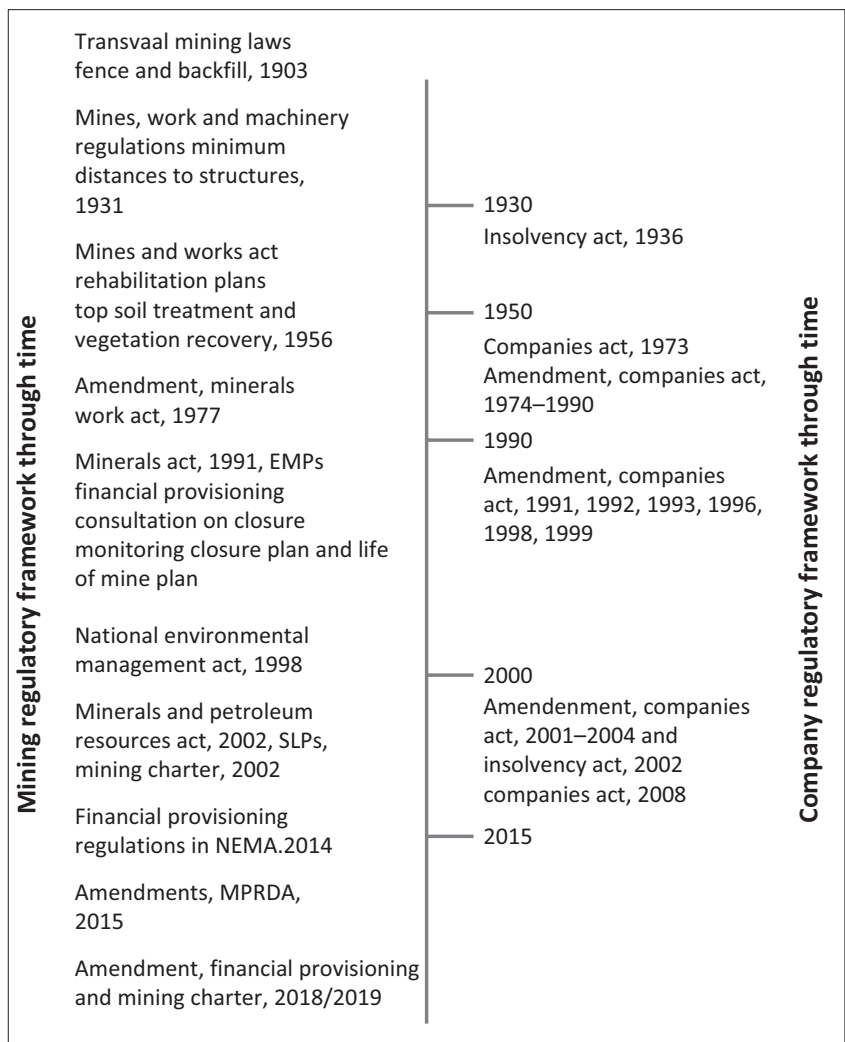

EMP, Environmental Management Programme; SLP, Social and Labour Plan; NEMA National Environmental Management Act; MPRDA, Mineral and Petroleum Resources Development Act.

FIGURE 5: Evolution of mining versus company legislation. 
The Mines and Works Act 27 of 1956 regulated the protection and preservation of the surface of mines, the treatment of wastewater and the combustion of waste-heaps. The regulations were extended to address safe undergrounds, dangerous TSFs, the abandonment of activities and the restoration of land. Comprehensive mine closure practices were established in the 1960s, 1970s and 1980s, with growing concerns over environmental issues related to mine closure, such as acid mine drainage and mine rehabilitation.

In 1977, the Mines and Works Act 27 of 1956 was amended to allow the Minister of Mineral and Energy Affairs to create environmental conservation regulations for mining areas and works. Rehabilitation was strongly introduced in the Minerals Act of 1991, which included closure plans, issuing of closure certificates and EMPs. The Act made provision for measures that mining companies should take when a mine closes at the end of its life-cycle. ${ }^{50}$ The main focus was restoration and management of the environment rather than socio-economic responsibilities towards the host communities. ${ }^{27}$

Developments in mining laws and the promulgation of the MPRDA and its regulations GNR 527 Government Gazette 26275 of 2004 (amended in 2013 and 2015) brought detailed improvements to closure models. The main aim of the MPRDA was to establish appropriate regulation to fulfil the requirements of the South African Constitution by ensuring orderly closure and minimising the state's liability for abandoned and derelict mines. The MPRDA and Mining Charter together ensure that mining companies act responsibly and uphold sustainable development in areas where they operate. The charter has evolved since 2004 to the 2018 version mentioned in the 'Socio-economic aspects of mine closure' section of this article.

Regarding the companies' regulatory frameworks, no major amendments were undertaken between 2004 and 2008. The Companies Act 71 of 2008 covers business rescue comprehensively. It refers to the Companies Act 61 of 1973 for companies considering liquidation through winding-up procedures.

\section{Concerns with policies}

As discussed in the previous section, Figure 4 summarises disjunctures between mining and environmental regulation versus company laws. Rapid progression and improvements occurred in the mining and environmental legislation but not in the companies' legislation. Mining legislation appears since 1903 when the legislation on fence and backfill was promulgated until recently with the amendments in the MPRDA in 2015 and Financial Provisions draft regulations in 2019. It is concerning that company laws have not progressed and adapted or kept up with changes to the mining and environmental laws.

South African legislation imposes on mine owners a duty of care. This duty includes adherence to common law, Acts of Parliament, provincial legislation and local governments' rules, regulations and by-laws, the Bill of Rights (in terms of the Constitution of the Republic of South Africa) and financial provisions for remediation of environmental degradation. Hence, South African policies pertaining to the environment and mining appear robust, with good intentions. However, gaps and loopholes exist in these regulations, which result in vulnerable communities suffering. There appears to be poor collaboration amongst the regulatory systems and government bodies. Overall, the Companies Act 61 of 1973 appears to be superior to other pieces of legislation.

The MPRDA and NEMA provide little clarity on the procedural rights for communities, particularly the extent of community involvement through public participation and the oversight of rehabilitation of land in their immediate vicinity. ${ }^{76}$ In cases of liquidation, there is no clarity on the procedural rights of mine employees and communities. Neither is there provision for periodic consultation before a mine is liquidated. In a study by Laurence, ${ }^{13}$ mine liquidation was not mentioned as a reason why a mine might close prematurely. The study reported only economic issues, such as a drop in commodity prices, geological matters, geotechnical, mechanical or equipment failure, environmental breaches or policy changes and community disputes.

Liefferink and Van Eeden ${ }^{77}$ argued that government departments do not regard mine closure and the enforcement of legislation as crucial matters. Indeed, the inadequate enforcement of mining laws appeared highly problematic in the BGMC and MMSA case studies. The enforcement of law in South Africa is weak and penalties for environmental degradation fail to discourage polluters. The Centre for Environmental Rights $^{78}$ found that the South African environmental compliance monitoring and enforcement system is ineffective owing to the lack of immediate monetary penalties for environmental violations by companies.

South Africa's mining law makes provision for several responsibilities relating to the closure of mines and rehabilitation of the land. These include contributions to a rehabilitation fund and plans for dealing with the effects on the workforce and community when the mine closes. They form part of the SLP. As a prerequisite for obtaining a mining right, this plan outlines how the company intends to share some of the benefits that flow from mining. However, according to LHRs, ${ }^{52}$ these obligations seem to be overlooked during liquidation. During the initiation of liquidation, neither the environment nor the mining state agencies tasked with the custodianship of natural resources are legally affected by the conditions triggering the need for liquidation. ${ }^{1}$ Lawyers for Human Rights ${ }^{52}$ thus recommended that a legal obligation be instituted to implement rehabilitation measures before a mine is allowed to enter liquidation. 


\section{Gaps and contradictions}

Mining companies that have mature assets can use liquidation to avoid the full expense of closure and rehabilitation, as described by Humby ${ }^{14}$ and LHRs. ${ }^{52}$ Lawyers for Human Rights $^{52}$ further argued that South Africa's gold sector appears to be experiencing a gradual decline, which could mean that many mining communities are deprived of the protection that mining law has attempted to create. In mining properties, there are dilemmas regarding the distribution of assets, with liquidators trying to find buyers, to keep mines functioning and avoid job losses or the cessation of basic services.

References to 'property' or 'assets' in the Companies Act 61 of 1973 are unclear regarding the inclusion or exclusion of trust funds for environmental rehabilitation, mining rights and communities affected by mining. The sudden closure of mining operations, with the concomitant lack of rehabilitation and mitigation measures, has resulted in $75 \%$ unemployment and environmental devastation. ${ }^{52}$ Environmental degradation occurs if there was no concurrent rehabilitation whilst the company was operational. When mines are closed abruptly, basic municipal services cease. The environment is subject to the ravages of mined-out land, including sinkholes and dust from unsecured and unvegetated TSFs.

A common thread in the cases of BGMC and MMSA was inadequate financial provisioning for environmental maintenance and rehabilitation. Mines are prematurely closed because of corporate distress, meaning companies are in debt and file for bankruptcy. The issue of liquidity amongst mines has direct implications for financial provisioning regulations. According to a study by the World Wide Fund South Africa ${ }^{79}$ (WWF-SA), various challenges affect the mining sector regarding the availability of funds to manage the impact of mining. The WWF-SA ${ }^{79}$ highlighted the flaws and gaps in the financial provision regulations; in addition, wide variation in the quality of environmental management plans and programmes contribute to inadequate funds.

When EMPs with substandard rehabilitation plans and financial calculations are accepted by the DMRE, problems regarding fund availability are exacerbated. This is one reason why Liefferink ${ }^{77}$ argued that the DMRE allows mining companies, especially in the gold sector, to be non-compliant. The DEA ${ }^{80}$ acknowledges the limited capacity of authorities to implement the regulations. However, the effects thereof are recognised in the long term, once a mine has closed legally or prematurely. The WWF-SA ${ }^{79}$ study observed that the environmental impacts of mining are severe, with measurable external costs that affect mining communities.

There are minimal or no independent public reviews of financial provision calculations. Therefore, these are inadequately audited. Section 24P of the NEMA does not specify that financial provisions should complete a compulsory annual peer review process to assess their sufficiency. However, in terms of the proposed (as yet unpublished) 2019 Regulations for Financial Provisions, that would be a requirement.

When mining companies are sold to other companies, mining rights need to be transferred between the two owners. The financial provision regulation does not explicitly require rights holders to amend or replace their financial provisions when transferring or amending their rights and selling their operations. A mining right or permit can be transferred without any evaluation of the financial provisions for rehabilitation. This scenario presents a challenge for the acquiring company. A mine can also be sold without its mining right or permit being transferred to the buyer, as occurred with Aurora Empowerment System and BGMC. ${ }^{14}$

The impact of the Insolvency Act 24 of 1936 and the Companies Act 61 of 1973 on the financial provisions is unclear given their ambiguity regarding salient issues. It is not clear, for example, whether financial provisions are protected or form part of the assets and creditors lists. The MPRDA does not clearly indicate whether company directors remain liable after the mining company has officially been liquidated. A notable gap is that a mining company may be deregistered through the process of winding-up (Chapter 14, Companies Act 61 of 1973) regardless of whether a closure certificate has been issued in terms of Section 43 of the MPRDA. Regulatory authorities are informed retrospectively about the process of winding-up, which can take as long as 5 years before final liquidation. This is a laborious process that does not accord well with the mine closure model.

There are currently no means to ensure the security of financial provisions during winding-up. The DMRE, insofar as its claim in respect of the financial provision is concerned, would not be a secured or preferred creditor upon insolvency. This scenario has implications for the DMRE in the event of insolvency of mines. As already noticed, the Companies Act 61 of 1973 does not articulate the mine closure model as its passage predated the mine closure standard (see Figure 5).

Overall, South Africa appears to still be coming to terms with the idea of sustainable development in mining. Mining communities are not yet adequately included in mining projects from their inception to their closure. Regarding sudden or final closure, there has been inadequate consideration of the future (post closure), social and community aspects. Countries such as Zimbabwe struggle with similar issues. In Penhalonga in Zimbabwe, there are several deep-level gold mines and small-scale mines. The surrounding community was mostly concerned about the immediate environmental impacts from mining, including water and air pollution and the loss of biodiversity, especially flora. Most mines surrounding Penhalonga have been closed for various reasons, with the political climate in the country being the main one. 
Blyvooruitzicht Gold Mining Company and MMSA are classical cases in South Africa; they illustrate how sudden mine closure through liquidation can devastate communities. Notably, at the time of liquidation, the owners of BGMC stated that worker disputes and in-fighting between trade unions, that is, the National Union of Mine Workers and the Association of Mineworkers and Construction Union - as well as several mine stoppages were factors that contributed to the financial difficulties.

The poor articulation of the Companies Act 61 of 1973 regarding mine closure has created an avenue for nonrehabilitation by mining companies. The result is a pollution challenge for the surrounding communities and natural environment. Furthermore, a policy gap exists regarding the requirement that a closure certificate must be applied for and approved by the Minister of Mineral Resources and Energy, whereas the DMRE is not a listed creditor according to the Companies Act 61 of 1973. Hence, during liquidation or business rescue, the DMRE is not involved. This situation has implications for the available financial provisions of the liquidated company, as the DMRE and DFFE cannot access the funds to remediate the environment during the mine's liquidation or business rescue process. The mining communities therefore suffer as a result of environmental degradation, with severe implications for their quality of life.

Unrehabilitated TSFs leading to environmental degradation, which then cascades to local communities, is a long-standing problem in the mine life-cycle. The problems that occur with sudden mine closure are the outcomes of poor compliance, poor implementation, poor integration, poor enforcement and gaps or conflicts in policies. At the mine project inception stage, it is important to estimate potential environmental and socio-economic impacts by conducting EIAs. An integrated strategy between government and other role-playing institutions is vital to the implementation of well-defined operational guidelines and final closure measures. However, some companies' operational standards and guidelines pertaining to the environment fail to integrate mining and environmental policies throughout the mine's life-cycle. This point was observed in the BGMC and MMSA case studies, where financial provisions were inadequate for environmental care, yet that was only recognised in the period of sudden mine closure.

During the operational stage of the mine, regulations about financial provision for rehabilitation and the continuous auditing of these funds, as well as active rehabilitation whilst mining continues, are essential policies. One practice that can affect these processes is the selling-off of marginal mines to smaller companies towards the end of the mine's life, as part of the closure strategy. This point remains a challenge. There is no legislation that prevents mining companies from doing this.

Junior mining companies operate over the short term and cannot handle the environmental liability and thus file for bankruptcy, leading to sudden mine closure.
The Mining Charter provides that mines should design and plan their operations so that adequate resources are available for the closure requirements of all operations. Section 28(2)(c) of the MPRDA contemplates that mines should report annually on their compliance with the Charter. ${ }^{17}$ However, where a mine is declared insolvent and subsequently closes, the responsibility is inherited by the State, which then must ensure the continuous rehabilitation of derelict and ownerless mines. Technically, the mine escapes liability. In any event, the rehabilitation fund the mine provided is often insufficient for continuous infrastructure management and rehabilitation.

At decommissioning and mine closure, mine operations are often left abandoned through care and maintenance orders or liquidation. When a mine is under care and maintenance, it is neither closed nor operational. Environmental and human rights activists view such orders as a 'faux legal term', referring to indefinitely warehousing a mine instead of spending on rehabilitation. ${ }^{77}$ In liquidation, the funds recouped are never allocated to environmental rehabilitation. Hence, the TSFs are left to impact the surrounding environment negatively.

\section{Lessons from other countries}

Our recommendations are that South Africa should adopt practices that work in other countries. For example, every closure should be viewed as site-specific, with local conditions determining the closure plan and post-mining outcomes. ${ }^{74}$ The National Orphaned/Abandoned Mines Initiates (NAOMI) project is an example of successful closure planning and mine closure. Another example is the Eden Project in the United Kingdom, where a former clay-mining pit was transformed into an environmental tourism attraction and educational charity. ${ }^{81}$

International experience indicates that mining companies and local communities are equally ill-prepared to deal effectively with mine closure and often fail to generate postmining economies. ${ }^{12}$ However, South Africa could adopt the proactive approach of $\mathrm{Chile,} \mathrm{which} \mathrm{monitors} \mathrm{mining} \mathrm{activities}$ with secure financial guarantees and warns surrounding communities about mine closure possibilities in advance. The main challenge regarding finances in South Africa is the mismanagement of funds by the government, with issues of corruption being reported daily in the country. Scarcity of funds is the reason why we have not achieved much in South Africa. The implementation of the public-private partnerships, although proposed by both the private sector and government has experienced problems with implementation. This is because of the mishandling of funds by the government and the bureaucratic processes involved when private partners are attempting to access funds for clean up in the custodianship of the government. The process of accessing these funds is cumbersome such that qualified partners trying to rehabilitate and clean up the abandoned mine sites never succeed to access them and thus give up. A mining company might need to self-monitor and set aside 
extra funds for rehabilitation and manage their concurrent rehabilitation as mine production progresses. Moreover, a mining company could use a third party to set aside funds during mining so that should sudden closure occur adequate provision of funds can be sourced.

South Africa can also learn from the ICMM, which in 2010 noticed that mine closure requires the attention of multiple stakeholders. The stakeholders include the government, the global mining industry, the local community and international organisations that are involved in ensuring sustainability in the mining sector. Stakeholder involvement is considered good practice internationally. The ICMM also allows for community participation in decision making from the early stages of mine development through to mine closure. The ICMM practices uphold ongoing maintenance and support of local mine communities even after the mine has closed. Both temporary mine closure and post-mine closure frameworks are required to address the impacts of sudden mine closure.

There are many lessons to gain from international experience. Firstly, mining is unique because of its transitory nature and its deep social and environmental impacts. ${ }^{37}$ Secondly, existing legislation concentrates on the natural or physical aspects of mine closure and on environmental rehabilitation rather than socio-economic rehabilitation. ${ }^{12}$ This narrow focus on the environment is evident globally, yet certain countries - such as Australia and Canada - display insight regarding the socio-economic impacts on the surrounding community.

Thirdly, there is increasing global consensus that planning for mine closure should be part of the overall life-cycle of a mine to pre-empt or reduce its negative socio-economic impact. ${ }^{81,82,83,84,85}$ Fourthly, ensuring a viable economy in the aftermath of mine closure has been realised in a few instances, notably in Australia and to a lesser extent in other countries. ${ }^{79}$ Fifthly, mine closure should be addressed through the establishment of appropriate partnerships between local actors, mining houses and government. ${ }^{83,84}$

Finally, the literature on deindustrialisation in developed countries indicates that an overarching response by government is required to assist communities affected by deindustrialisation. ${ }^{86}$ Many reindustrialisation processes have involved local partnerships, some form of national government funding and substantial public sector input. ${ }^{86}$

\section{Conclusion}

This article has shown that mining companies in South Africa are currently able to use devious but legal strategies to evade their costly obligations. The use of the winding-up procedure by the BGMC and MMSA illustrates how a company can prevent the adoption of legislation or investigations pertaining to mine closure. A mining company can be dissolved or cease to exist through winding-up, which renders it unavailable to deal with the legal requirements of closure, community engagement, rehabilitation and financial provisions. These events can adversely impact a company's investments. The NEMA 'polluter pays' principle is clear, but loopholes exist through other pieces of legislation, including the Companies Act 61 of 1973 and the Companies Act 71 of 2008. The situation was demonstrated by the cited case studies.

This article also demonstrates how a company - such as MMSA - may gain favour from the state and may be allowed to operate without an issued mining right until liquidation. In the case of MMSA, the mining right was granted but not issued, and the company failed to meet multiple financial and social provisions. Despite the lack of a valid mining licence, MMSA continued its operations, amid many documented complaints of environmental contravention by the surrounding communities and NGOs. Despite Parliament recommending prosecution and civil suits for company directors and shareholders in their personal capacities, to recoup some of the costs, the National Prosecuting Authority has been silent on the matter to date.

Companies sometimes leverage their power with government to obtain favourable treatment, security and impunity. Where corporate interests have 'captured' the government or its agents, communities, human rights defenders and other rights holders risk losing fundamental protections and access to justice. In the MMSA case, it appears that the company benefited from the state's lack of exercise of power or implementation of existing policy. The result was to the detriment of the surrounding communities. In this situation, the company avoided responsibility and liability; indeed, its actions seemed to be condoned by the state through nonenforcement by the DMRE.

The BGMC and MMSA case studies are classical examples of the use of legal strategies, such as the winding-up process, by mining companies. These manifest in a wide array of actions that obstruct justice, distort the facts and frustrate remedies for the affected communities. Hence, although South African mine closure laws appear comparable to the laws of other countries, there are gaps in compliance. It is clear that distressed mining companies are poorly managed, as observed in the cases of MMSA and BGMC. This lack of management and compliance ultimately reflects inadequate implementation by the DMRE, as well as the observed gaps in legislation on mining, companies and the environment.

Insufficient social impact assessment, contingency planning and public participation are evident in the mine closure planning process in South Africa. There is no specific mention of sudden mine closure planning in the MPRDA, the Regulations for Financial Provisioning or the NEMA. This silence is risky for both the mining communities and the environment.

Finally, the participation of the community, NPOs and activists in the regulatory processes is essential. A request to relevant stakeholders and environmental management systems is made through this article, for authorities to strengthen implementation and enforcement of legislation. 


\section{Acknowledgements}

The authors would like to acknowledge Ingrid Watson for advisory on the key concepts discussed in the article.

\section{Competing interests}

The authors declare that they have no financial or personal relationships that may have inappropriately influenced them in writing this article.

\section{Authors' contributions}

M.M. and E.A. conceived of the presented idea. M.M. developed the theory and conceptualised the key message. E.A. conceptualised and verified the methods. E.A. and R.M. provided guidance and supervision. R.M. edited the draft and supervised the findings of this work. All authors contributed to the final manuscript.

\section{Ethical considerations}

This article followed all ethical standards for a research without direct contact with human or animal subjects.

\section{Funding information}

The authors received no financial support for the research, authorship, and/or publication of this article.

\section{Data availability}

The authors confirm that the data supporting the findings of this study are available within the article and its supplementary materials.

\section{Disclaimer}

The views and opinions expressed in this article are those of the authors and do not reflect the official policy or position of any affiliated agency of the authors.

\section{References}

1. Humby TL. One environmental system aligning the laws of the environmental management of mining in SA26 (3). J Energy Nat Resour Law. 2015;33(2):110-130. https://doi.org/10.1080/02646811.2015.1022432

2. Companies Act 61 of 1973, Government Gazette. Republic of South Africa [statute on the Internet]. Pretoria: Government Printer; [cited 2020 May 5]. Available from: https://www.wylie.co.za/wp-content/uploads/COMPANIES-ACT-NO.-61OF-1973.pdf

3. Companies Act 71 of 2008. Government Gazette. Republic of South Africa [statute on the Internet]. Pretoria: Government Printer; [cited 2020 May 5]. Available from: https://www.gov.za/documents/companies-act?gclid=EAlalQobChMI69GV 87rO8AIVCRF7Ch0pqQBaEAAYASAAEgKaEfD BwE

4. Mpanza M, Adam E, Moolla R. Dust deposition impacts at a liquidated gold mine village: Gauteng province in South Africa. Int J Environ Res Public Health. 2020;17(14):4929. https://doi.org/10.3390/ijerph17144929

5. Moreno T, Querol X, Alastuey A, Ballester F, Gibbons W. Airborne particulate matter and premature deaths in urban Europe: The new WHO guidelines and the challenge ahead as illustrated by Spain. Eur J Epidemiol. 2006;22:1-5. https://doi. org/10.1007/s10654-006-9085-y

6. Adler RA, Claassen M, Godfrey L, Turton RA. Water, mining and waste: An historical and economic perspective on conflict management in South Africa. Econ Peace Secur J. 2007;2(2):367-372. https://doi.org/10.15355/epsj.2.2.33

7. Digby C. Mine closure \& rehabilitation: From dereliction to accountability? Presentation: Centre for Sustainability in Mining and Industry. Johannesburg: University of the Witwatersrand; 2016
8. Minerals Council South Africa. Facts and figures: Overview of the South African mining industry [homepage on the Internet]. Minerals Council South Africa Website; 2018 [cited 2018 Jan 20]. Available from: https://www.mineralscouncil.org.za/

9. World Bank. It's not over when it's over: Mine closure around the world. Washington, DC: World Bank and International Finance Corporation; 2002.

10. Laurence DC. Optimising mine closure outcomes for the community - Lessons learnt. Minerals Energy/Raw Materials Report. 2002;17(1):27-38. https://doi. org/10.1080/140410402760018084

11. Milaras M, McKay TJM. Mine closure in South Africa: A survey of current professional thinking and practice conference. Sandton: Mine Closure; 2014.

12. Marais L. Resources policy and mine closure in South Africa: The case of the Free State Goldfields. Resour Policy J. 2013;38(3):363-372. https://doi.org/10.1016/j. resourpol.2013.04.004

13. Constitution of the Republic of South Africa. Government Gazette (No. 108). Pretoria: Government Printer; 1996.

14. Humby TL. Facilitating dereliction? How South African legal regulatory framework enables mining companies to circumvent closure duties [homepage on the Internet]. 2014 [cited 2018 Jan 20]. Available from: http://www.academia. edu/8621292/Facilitating_dereliction_How_SouthAfrican_legal_regulatory_ framework_enables_mining_companies_to_circumvent_closure_duties

15. Piper DLA. Insolvencies at the coalface: A global view of mining sector restructurings [homepage on the Internet]. 2013 [cited 2019 Mar 8]. Available from: https://www.dlapiper.com/en/southafrica/insights/publications/2013/03/ insolvencies-at-the-coalface-a-global-view-of-mi_/

16. World Bank Group. Guidance notes for the implementation of financial surety for mine closure [homepage on the Internet]. 2008 [cited 2019 Jun 12]. Available from: https://openknowledge.worldbank.org/handle/10986/18386

17. Mineral and Petroleum Resources Development Act: Regulations [statute on the Internet]. [cited 2019 Jun 01]. Available from: https://www.gov.za/sites/default/ files/gcis_document/201409/a28-020.pdf

18. Stuit A. 400000 South Africans face famine by black gold mine closure. Digit J [serial online]. 2009 [cited 2019 Jun 12]. Available from: https://doi.org/ $10.2307 / 2265783$

19. Van der Walt N. Myners huis toe, geen geld. Planne vir noodfondse, skoolhulp aan die gang. Noordwes Beeld, 1. April 3; 2009

20. Olalde M. SA's failed system of mine closure [homepage on the Internet]. 2017 [cited 2018 Feb 5]. Available from: https://www.iol.co.za/news/opinion/sasfailed-system-of-mine-closure-7117963

21. South African National Assembly. Report of the portfolio committee on mineral resources on its oversight visit North West and Gauteng on the 13-14 September 2018, dated 07 November 2018, announcements, tablings and committee reports [homepage on the Internet]. Cape Town: Parliament of the Republic of South Africa; 2018 [cited 2019 Nov 4]. Available from: https://dc.sourceafrica.net/ Africa; 2018 [cited 2019 Nov 4]. Available from: https://dc.sourceafrica.ne
documents/118553-Portfolio-Committee-on-Mineral-Resources-Final.html

22. ICMM. Planning for integrated mine closure: Toolkit. London: International Council on Mining and Metals; 2019.

23. Stacey J, Naude A, Hermanus M, Frankel P. The economic aspects of mine closure and sustainable development. Literature overview of lessons for the socioeconomic aspects of closure 2 (2) Project 73835 of the Coaltech Research Association, Report. Johannesburg: Journal of the Southern African Institute of Mining and Metallurgy, 2010a; p. 1-32.

24. Fourie A, Brent AC. A project-based mine closure model (MCM) for sustainable asset life cycle management. J Clean Prod. 2008;14(12-13):1085-1095. https:// doi.org/10.1016/j.jclepro.2004.05.008

25. Swart E. The South African legislative framework for mines [homepage on the Internet]. Southern African Institute of Mining and Metallurgy (SAIMM); 2003 [cited 2019 Nov 10]. Available from: https://www.saimm.co.za/Conferences/ MineClosure/001-Swart.pdf

26. Humby TL. The spectre of perpetuity liability for treating acid water on South Africa's Goldfields: Decision in Harmony II. J Energy Nat Resour Law. 2013;31(4):465-466. https://doi.org/10.1080/02646811.2013.11435343

27. National Environmental Management Act. Regulations: Financial provision for prospecting, exploration, mining or production operations [statute on the Internet]. [cited $2020 \mathrm{Feb} 3$ ]. Available from: https://www.gov.za/sites/default/ files/gcis_document/201511/39425rg10526gon1147.pdf

28. Department of Minerals and Energy. A strategic framework for implementing sustainable development in the South African minerals sector: Towards developing sustainable development policy and meeting reporting commitments. Discussion document, 2nd dreft [homepage on the Internet]. Pretoria: South etoria: South African National Department of Minerals and Energy; 2009 [cited 2021 Jul 19]. Available from: https://www.gov.za/sites/default/files/gcis_document/201409/ sd-strategic-framework-minerals-april-2009.pdf

29. Guideline for the submission of a social and labour plan as required in terms of regulation 46 of the Mineral and Petroleum Resources Development Act (Act 28 of 2002) [statute on the Internet]. [cited 2021 Apr 14]. Available from: https:// www.dmr.gov.za/Portals/0/social\%20and\%20labour\%20plan_guideline.pdf

30. National Environmental Management Act 1998: Proposed regulations pertaining to: Financial provisioning for rehabilitation, and remediation of environmenta damage caused by reconnaissance, prospecting, exploration, or mining production damage caused by reconn
operations. Unpublished.

31. National Environmental Management Act 107 of 1998 [statute on the Internet] [cited 2020 Oct 3]. Available from: https://www.gov.za/documents/nationalenvironmental-management-act?gclid=EAlalQobChMI3dqlk77Q8AIVgQWiAx1aU QRiEAAYASAAEgJjbvD_BwE 
32. Milaras M. The judicious use of environmental sustainability indicators in support of mine closure in South Africa [statute on the Internet]. MSc. Department of Geography, Environmental and Energy Studies, University of Johannesburg. 2014 [cited 2019 July 8]. Available from: https://www.researchgate.net/ 2014 cited 2019 July 8]. Available from: https://www.researchgate.net/ publication/299642798_The_Judicious_Use_of_Environm
Indicators in Support_of_Mine_Closure_in_South_Africa

33. Council for Geoscience Annual Report [homepage on the Internet]. [cited 2021 May 14]. Available from: https://www.geoscience.org.za/images/AnnualReports/ CGSAnnualReport19-10-2016.pdf

34. Siyongwana PQ, Shabalala A. The socio-economic impacts of mine closure on GeoJournal. 2019;84:367-380. https://doi.org/10.1007/s10708-018-9864-5

35. Van Eeden ES. Legal issues concerning mine closure and social responsibility on the West Rand. J Trans-disciplinary Res S Afr. 2009;5(1):191-208.

36. Du Plessis A. Development of a risk-based mine closure cost calculation model [homepage on the Internet]. Johannesburg: The South African Institute of Mining and Metallurgy; 2011 [cited 2021 .za/Journal/v106n06p443.pdf

37. Hamann R. Corporate social responsibility, partnerships and institutional change: (2004:28(4):278-290. https://doi.org/10.1111/j.1477-8947.2004.00101.x

38. Oelofse SHH, Hobbs PJ, Rascher J, Cobbing JE. The pollution and destruction threat of gold mining waste on the Witwatersrand: A West Rand case study. Natural resources and the environment. Pretoria: CSIR; 2007.

39. Broad-based socio- economic empowerment charter for the mining and minerals industry [statute on the Internet]. [cited 2020 July 19]. Available from: https:// www.gov.za/sites/default/files/gcis_document/201809/41934gon1002.pdf

40. Naidoo S. Acid mine drainage in South Africa: Development actors, policy impacts and broader implications [homepage on the Internet]. New York: Springer Brief in Environmental Science; 2017 [cited 2021 Jul 19]. Available from: https://link. springer.com/book/10.1007/978-3-319-44435-2\#about

41. Durand J. The Impact of gold mining on the Witwatersrand on the rivers and kars system. J Afr Earth Sci. 2016;68(3):24-43. https://doi.org/10.1016/j.jafrearsci. 2012.03.013

42. South African Human Rights Commission. National hearing on the underlying socio-economic challenges of mining-affected communities in South Africa [homepage on the Internet]. Johannesburg: South African Human Rights Commission; 2016 [cited 2021 Jul 19]. Available from: http://www.sahrc.org.za/ home/21/files/SAHRC\%20Mining\%20communities\%20report\%20FINAL.pdf

43. AngloGold Ashanti. AngloGold Ashanti environmental report. Woodlands project good progress being made with phytoremediation [homepage on the Internet]. 2004 [cited 2020 Feb 2]. Available from: https://www.academia.edu/5257660/ The_Mine_Woodlands_Project_in_the

44. Nkosi V, Wichmann J, Voyi K. Chronic respiratory disease among the elderly in South Africa: Any association with mine dumps. Environ Health. 2015;14:33. https://doi.org/10.1186/s12940-015-0018-7

45. National Environment Management: Air Quality Act 39 of 2004. [statute on the Internet]. [cited 2021 May 13]. Available from: https://www.gov.za/documents/ national-environment-management-air-quality-act?gclid=EAlalQobChMI-ZzkkfbQ 8AIVOAN7ChOpEQMKEAAYASAAEgLCKPD_BwE

46. Benchmarks Foundation Soweto Report. Waiting to inhale: A survey of household health in four mines affected communities [homepage on the Internet].
2017 [cited 2018 Sep 3]. Available from: https://www.researchgate.net/ 2017 [cited 2018 Sep 3]. Available from: https://www.researchgate.net/ publication/320225273_Soweto_Report_Waiting_to_t
household health in four_mine-affected_communities

47. Harvard Law School International Human Rights Clinic. The cost of gold: Environmental, health and human rights consequences of gold mining in South Africa's West and Central Rand [homepage on the Internet]. 2016 [cited 2020 Feb 3]. Available from: https://hrp.law.harvard.edu/wp-content/uploads/2016/11/ The-Cost-of-Gold-Full-Report-Final.pdf

48. Coetzee H, Nengobela NR, Vorster C, Sebake D, Mudau S. South Africa's strategy for the management of derelict and ownerless mines [homepage on the Internet]. Proceedings of the 3rd International conference on mine closure, 14-17 October. Johannesburg: Department of Mineral Resources, 2008 [2021 Jul 2019]; pp 4-29. Available from: https://www.researchgate.net/ publication/263067437_Strategy_for_the_management_of derelict_and ownerless_mines_in_South_Africa [2021 July 2019].

49. Heyl AJ. Effect of mining effluent on the distribution of freshwater invertebrates in the Tweelopiespruit, Gauteng. Unpublished BSc. Honours Research Report, Department of Zoology, University of Johannesburg; 2006.

50. Ackerman M, Botha D, Van der Waldt G. Potential socio-economic consequences of mine closure. J Trans-disciplinary Res S Afr. 2018;14(1):a458. https://doi. org/10.4102/td.v14i1.458

51. DRD Gold. Environmental impact assessment [homepage on the Internet] 2007 [cited 2018 Mar 17]. Available from: https://sahris.sahra.org.za/sites/ default/files/additionaldocs/1_BVG4880_DraftEIAEMP_0.pdf

52. Lawyers for Human Rights (LHR). Blyvooruitzicht Mine Village: The human toll of state and corporate abdication of responsibility in South Africa [homepage on the Internet]. 2017 [cited 2018 Apr 3]. Available from: http://www.lhr.org.za/

53. Yao S. Blyvoor business rescue proceedings terminated [homepage on the Internet] 2011 [cited 2021 Jun 20]. Available from: http://www.ibtimes.com/blyvoor-businessrescue-proceedings-terminated-368430.

54. Saaiman M. Affidavit: In the ex parte application of Blyvooruitzicht. Johannesburg Gold Mining Company Limited, South Gauteng High Court; 2013.

55. King S. Blyvoor: Legal minefield is a deadly hazard [homepage on the Internet]. Johannesburg: Mail and Guardian; 2013 [cited 2021 Jul 19]. Available from: https://mg.co.za/article/2013-11-21-legal-minefield-is-a-deadly-hazard/
56. Department of Mineral Resources. Report of the joint standing committee on the Financial Management of Parliament on the Parliament of the Republic of South Africa's 2017/2018. Annual Report. Pretoria: Government Printers; 2018.

57. Andrews C. Maraboli L, Strongman J. An asset for competitiveness: Sound environmental management in mining countries. Washington, DC: World Bank; 2002.

58. Smith H, Nindi S, Bechaus G. Complex commons under threat of mining: The process for and content of community consent. The paper submitted for presentation to the 2011 IASC-FES conference, Sustaining Commons, Sustaining our Future: Governance of the Commons; 2011 Jan 10; Hyderabad, India; 2011.

59. Clark AL, Clark JC. An international overview of legal frameworks for mine closure [homepage on the Internet]. Eugene: Environmental Law Alliance Worldwide; 2005 [cited 2021 Jul 19]. Available from: http://www.elaw.org/node/3715

60. International Council on Mining and Metals (ICMM). Planning for integrated mine closure: Toolkit. London: ICMM; 2008.

61. International Council on Mining and Metals (ICMM). Projects. London: ICMM; 2010.

62. Australian and New Zealand guidelines for fresh and marine water quality homepage on the Internet]. Volume 1. The guidelines/Australian and New Zealand Environment and Conservation Council, Agriculture and Resource Managemen Council of Australia and New Zealand [cited 2021 May 18]. Available from: https:// www.waterquality.gov.au/sites/default/files/documents/anzecc-armcanz-2000 guidelines-vol1.pdf

63. Department of Minerals and Energy. Minerals and Petroleum Resources Development Act (1999), 448 Government Gazette No. 23922. Pretoria: Government Printers; 1999

64. Department of Mines \& Petroleum (DMP). Guidelines for preparing mine closure plans [homepage on the Internet]. Perth: Department of Mines and Petroleum; 2015 [cited 2021 Jul 19]. Available from: http://www.dmp.wa.gov.au/Documents/ 2015 [cited 2021 Jul 19]. Availab

65. Faizuldayeva Z. A comparative study of regulatory approaches to mine closure with a special emphasis on the current situation in the former Soviet Union [homepage on the Internet]. Perth: SRK Consulting; 2016 [cited 2021 Jul 19]. Available from: https:// dxi97tvbmhbca.cloudfront.net/upload/user/image/AComparativeStudyof RegulatoryApprochesto MineClosure_2016_020191128181753026.pdf

66. Miller C. Financial assurance for mine closure and reclamation: A study prepared for the International Council on Mining and Metals [homepage on the Internet] London: International Council on Mining and Metals; 2005 [cited 2021 Jul 19]. Available from: https://www.extractiveshub.org/servefile/getFile/id/2888

67. White B., Doole GJ, Pannell DJ, Florec V. Optimal environmental policy design for mine rehabilitation and pollution with a risk of non-compliance owing to firm insolvency. Aust J Agric Res Econ. 2012;56:280-301. https://doi.org/10.1111/j. 1467-8489.2012.00591.x

68. Kabir MZ, Rabbi F, Chowdhury MB, Akbar D. A review of mine closure planning and practice in Canada and Australia. World Rev Bus Res. 2015;5(3):140-159.

69. Mondaq Australia. Mine site closure in WA and the new rehabilitation fund [homepage on the Internet]. 2017 [cited 2018 Aug 5]. Available from: https:// www.mondaq.com/australia/mining/267580/mine-site-closure-in-wa-and-thewww.mondaq.com/aust

70. Siwik R, Clemens M. Mine closure-past, present and perpetuity mine closure [homepage on the Internet]. Perth: Austrilian Centre for Geomachanics; 2015 [cited 2021 July 19]. Available from: https://papers.acg.uwa.edu.au/p/1608_23 mccullough/

71. Canadian Government Mine Closure. Canadian Government, NR. (Undated, post 2000) Mine Closure. Mining Toolkit 4. 2000

72. Province of British Columbia. British Columbia mine reclamation securities. Vancouver: Government of British Columbia; 2015

73. Lombard D. Law enforcement in the South African gold mining sector: The nexus between company, environmental and equity law. Master's thesis [homepage on of South Africa (UNISA); 2018 [cited 2021 July 19]. Available from: http://uir.unisa. of South Africa (UNISA); 2018
ac.za/handle/10500/25084

74. Cowan WR, MacKasey WO, Robertson GA. The policy framework in Canada for mine closure and management of long-term liabilities: A guidance document [homepage on the Internet]. Hudson Quebec: Cowan Minerals Ltd.; 2010 [cited 2021 July 19]. Available from: http://www.abandoned-mines.org/wp/wpcontent/uploads/2015/09/Tremblay-G.-Enviromine2011.pdf

75. Castrilli J. Report on the legislative, regulatory and policy framework. Respecting collaboration, liability and funding measures in relation to orphaned/abandoned, contaminated, and operating mines in Canada [homepage on the Internet]. Prepared for the National Orphaned/Abandoned Mines Initiative; 2007 [cited 2018 Dec 17]. Available from: http://www.abandoned-mines.org/pdfs/Jurisdictional LegislativeReview.pdf

76. Krause RD, Snyman LG. Rehabilitation and mine closure liability: An assessment of the accountability of the system to communities [homepage on the Internet]. 2014 [cited 2018 Mar 17]. Available from: https://www.wits.ac.za/media/witsuniversity/faculties-and-schools/commerce-law-and-management/researchentities/cals/documents/Rehabilitation\%20and\%20mine\%20closure\%20liability. pdf

77. Liefferink M, Van Eeden ES. Environment risks and hazards pertaining to acid mine drainage and radioactivity within the Witwatersrand Gold Fields Federation for a Sustainable Environment [homepage on the Internet]. Vanderbijlpark: The Journal for Transdisciplinary Research in Southern Africa; 2010 [cited 2021 July 19]. Available from: https://cer.org.za/wp-content/uploads/2010/05/Van-EedenLiefferink-and-Durand-2009-AMD-and-Wonderfonteinspruit.pdf

78. Centre for Environmental Rights (CER). When mines break environmental laws. The Federation for a Sustainable Environment Website; 2013 [cited 2013 Apr 20] Available from: https://cer.org.za/wp-content/uploads/2013/02/When-MinesBreak-Environmental-Laws1.pdf 
79. World Wide Fund for Nature-SA. 2012 [cited 2018 June 29]. Available from: https://wwf.panda.org/wwf_offices/south_africa

80. Liefferink M. Federation for a sustainable environment presentation on the efficacy of South Africa's environmental impact assessment (EIA) regime: A call for responses to government's legislative and policy strengthen environmental governance and the sustainability of our developmental growth path. Sandton: Federation for a Sustainable Environment; 2008. Aug 29]. Available from: https://www.edenproject.com/new-edens/eden-projectportland-uk

82. Andrews-Speed P, Ma G, Shao B, Liao C. Economic responses to the closure of small-scale coal mines in Chongqing, China. Resour Policy J. 2005;30(1):39-54. https://doi.org/10.1016/j.resourpol.2004.12.002
83. Cesare $P$, Maxwell P. Mine closure legislation in Indonesia: The role of mineral industry involvement. Nat Resour Forum. 2003;27(1):42-52. https://doi.org/ 10.1111/1477-8947.00039

84. Hilson G., Murck B. Sustainable development in the mining industry: Clarifying the corporate perspective. Resour Policy. 2000;26(4):227-238. https://doi.org/ 10.1016/S0301-4207(00)00041-6

85. Warhurst A, Macfarlane M, Wood G. Issues in the management of socioeconomic impacts of mine closure: A review of challenges and constraints. In: Warhurst A, Noronha L, editors. Environmental policy in mining: Corporate strategy and planning for closure. Boca Raton, FL, Lewis Publishers, 2000; pp. 81-99.

86. Humphreys DA. A business perspective on community relations in mining. Resou Policy. 2000;26(3):127-131. https://doi.org/10.1016/S0301-4207(00)00024-6 